\title{
Extrapolation factors for characterizing freshwater ecotoxicity effects
}

\author{
Aurisano, Nicolo; Albizzati, Paola Federica; Hauschild, Michael Zwicky; Fantke, Peter
}

Published in:

Environmental Toxicology and Chemistry

Link to article, DOI:

10.1002/etc. 4564

Publication date:

2019

Document Version

Peer reviewed version

Link back to DTU Orbit

Citation (APA):

Aurisano, N., Albizzati, P. F., Hauschild, M. Z., \& Fantke, P. (2019). Extrapolation factors for characterizing freshwater ecotoxicity effects. Environmental Toxicology and Chemistry, 38(11), 2568-2582.

https://doi.org/10.1002/etc.4564

\section{General rights}

Copyright and moral rights for the publications made accessible in the public portal are retained by the authors and/or other copyright owners and it is a condition of accessing publications that users recognise and abide by the legal requirements associated with these rights.

- Users may download and print one copy of any publication from the public portal for the purpose of private study or research.

- You may not further distribute the material or use it for any profit-making activity or commercial gain

- You may freely distribute the URL identifying the publication in the public portal

If you believe that this document breaches copyright please contact us providing details, and we will remove access to the work immediately and investigate your claim 
Nicolo Aurisano ORCID iD: 0000-0003-3651-1307

Peter Fantke ORCID iD: 0000-0001-7148-6982

\section{Extrapolation factors for characterizing freshwater ecotoxicity effects}

Running head: Extrapolation factors for freshwater ecotoxicity

\section{List of authors and affiliations:}

Nicolò Aurisano ${ }^{\mathrm{a}}$, Paola Federica Albizzati ${ }^{\mathrm{b}}$, Michael Hauschild ${ }^{\mathrm{a}}$, Peter Fantke ${ }^{\mathrm{a} *}$

${ }^{a}$ Quantitative Sustainability Assessment, Department of Management, Technology and

Economics, Technical University of Denmark, Produktionstorvet 424, 2800 Kgs.

Lyngby, Denmark

${ }^{b}$ Department of Environmental Engineering, Technical University of Denmark, Bygningstorvet 115, 2800 Kgs. Lyngby, Denmark

*Corresponding author: Tel.: +45 45254452, fax: +45 45933435. E-mail: pefan@dtu.dk

Acknowledgements

We thank Nienke Kirchhübel for her support in the substance data preparation.

This work was supported by the 'Global Best Practices on Emerging Chemical Policy

Issues of Concern under the Strategic Approach to International Chemicals Management

This article has been accepted for publication and undergone full peer review but has not been through the copyediting, typesetting, pagination and proofreading process, which may lead to differences between this version and the Version of Record. Please cite this article as doi: 10.1002/etc.4564.

This article is protected by copyright. All rights reserved. 
(SAICM)' of the United Nations Environment Programme (grant no. S1-32GFL-000632)

and the OLCA-Pest project financially supported by ADEME (grant no. 17-03- C0025).

\begin{abstract}
Various environmental and chemical assessment frameworks including ecological risk assessment and life cycle impact assessment aim at evaluating long-term ecotoxicity effects. Chronic test data are reported under the European REACH regulation for several chemicals. However, chronic data are missing for a large fraction of marketed chemicals, for which acute test results are often available. Utilizing acute data requires robust extrapolation factors across effect endpoints, exposure durations and species groups. We propose a decision tree based on strict criteria for curating and selecting high quality aquatic ecotoxicity information available in REACH for organic chemicals, to derive a consistent set of generic and species group-specific extrapolation factors. Where ecotoxicity effect data are not available at all, we alternatively provide extrapolations from octanol-water partitioning coefficient as predictor for chemicals with non-polar narcosis as mode of action. Extrapolation factors range from 0.2 to 7 and are higher when simultaneously extrapolating across both effect endpoints and exposure durations. Our results are consistent with previously reported values, while considering more endpoints, providing species-group specific factors, and characterizing uncertainty. Our proposed decision tree can be adapted to curate information from additional data sources as well as data for other environments, such as sediment ecotoxicity. Our approach and robust extrapolation factors help to increase the substance coverage for characterizing ecotoxicity effects across chemical and environmental assessment frameworks.
\end{abstract}

This article is protected by copyright. All rights reserved. 
KEYWORDS: Effect factor; chemicals; ecotoxicological effects; life cycle impact assessment; characterization modelling

Introduction

Assessing ecotoxicological impacts on freshwater ecosystems from chemical exposure is an important component in various environmental and chemical management frameworks. This includes environmental risk assessment (ERA) for evaluating ecological health risks associated with chemicals in a regulatory context (Mccarty et al. 2018), and life cycle impact assessment (LCIA) for evaluating the environmental performance of products and services (Fantke et al. 2018). Both frameworks are based on evaluating the chemicals' fate and effects; however, they differ considerably in their purposes and underlying assumptions. ERA aims at ensuring safety of ecosystem structures and functions, using as protective metric the ratio between the Predicted NoEffect Concentration (PNEC) and the Predicted Environmental Concentration (PEC) (Guérit et al. 2008; ECHA 2012). Ecotoxicological test results to derive PNECs are preferably based on the No-Observed Effect Concentration (NOEC) from chronic tests, defined as an actual tested concentration of a compound at which no effects were observed on the tested species in a certain timeframe, for the most sensitive species. In contrast, LCIA aims at quantifying and comparing the overall environmental pressure from chemical emissions on entire ecosystems along entire product and service life cycles. To ensure comparability across chemicals and life cycles, LCIA relies on average or most representative estimates for chemicals' chronic ecotoxicological effect pressure across all relevant species (Rosenbaum 2015). As metric, effect concentrations (ECX) are used, eliciting effects on, for example, 50\% (EC50) or 10\% (EC10) of the exposed 
organisms over the background effect level (Fantke et al. 2018; Owsianiak et al. 2019). Such comparative context, using any given ecotoxicity metric, is also relevant for prioritizing chemicals for potential substitution, that is to identify viable alternatives to harmful chemicals in products (Fantke et al. 2015; Steingrímsdóttir et al. 2018).

Regardless the assessment context, there is for the wide range of marketed chemicals a lack of chronic NOEC and ECx test data, which can be readily used for ecotoxicity characterization without extrapolation from other (e.g., acute) test data (Cronin 2017). Ecotoxicity characterization hence relies for various chemicals on the use of acute data. Utilizing acute data, however, requires robust extrapolation factors toward desired effect endpoints (i.e., NOEC, EC10, and EC50), across exposure durations and for different species groups. Existing extrapolation approaches either introduce predefined safety factors (ECHA 2012), or use generic acute-to-chronic extrapolation ratios based on analyzing few chemicals Recently proposed extrapolation studies often do not consider differences across species groups (e.g., Warne et al. 2015; O. King et al. 2017; Posthuma et al. 2019), which however might be as relevant as differences between endpoints or exposure durations (Dong et al. 2014; Scholz et al. 2018). Other studies, which proposed factors for specific species groups, usually focus on selected endpoints (e.g., Raimondo et al. 2010; May et al. 2016). To obtain robust extrapolation factors, however, it is important to include chemicals and endpoints for which both acute and chronic data are reported, ideally for the same species or for many species within the same species group (Lehmann et al. 2010).

In more than 100,000 dossiers covering almost 20,000 unique substances as of 2019, numerous ecotoxicological test data have been submitted under the European

This article is protected by copyright. All rights reserved. 
Registration, Evaluation, Authorization and Restriction of Chemicals (REACH) regulation in support of a safe management of industrial chemicals (EC 2006; Cesnaitis et al. 2014; Sobanska et al. 2014; Tarazona et al. 2014; Versonnen et al. 2014; Saouter et al. 2019a,b). REACH is currently one of the most comprehensive and updated online databases of physicochemical, human toxicity and ecotoxicity information for chemicals. Using REACH as a potential data source in various policy and science fields has been widely discussed (Askham 2012; Luechtefeld et al. 2016; Gustavsson et al. 2017; Müller et al. 2017; Saouter et al. 2017a,b, 2019a,b; Fantke et al. 2018). A common conclusion across studies is that data submitted under REACH require a careful curation (e.g., species name harmonization, unit checks) before they are used. Furthermore, not for all registered chemicals the desired chronic ecotoxicity information is available to meet data requirements of existing characterization methods (Igos et al. 2014; Müller et al. 2017; Fantke et al. 2018).

To support a wider use of available ecotoxicological effect information, extrapolation factors need to be developed based on data reported under REACH, which account for differences between effect metrics, species groups and exposure test durations, including uncertainty information. While such extrapolation factors should be applicable to characterize ecotoxicological effects of all relevant chemicals, they should be derived from chemicals with highest data coverage and quality to ensure high robustness. This will ultimately allow for a broader consideration of ecotoxicity data across assessment frameworks, based on an increased reliability of extrapolations between endpoints and including a wider range of available test results. With that, the overall goal of the present study is to improve the data basis for ecotoxicity

This article is protected by copyright. All rights reserved. 
characterization with focus on the following specific objectives: First, we select and scrutinize (pre-process) ecotoxicity data for organic chemicals registered under REACH, applying a restrictive set of criteria in a decision tree to derive a maximum quality dataset. Second, we derive extrapolation factors with respect to different endpoints and exposure durations for specific species groups and across species (generic). Finally, we discuss the relevance of species sensitivities as well as extrapolating effects from information on lipophilicity and mode of action, where ecotoxicological data are missing. Our factors are proposed for application in environmental and chemical management frameworks.

Methods

Defining data selection criteria

We start from dossiers submitted under REACH as the most comprehensive data source today regarding ecotoxicological test information. A chemical's annual production/import volume into Europe dictates the level of information reporting requirements under REACH (ANNEX VII-X) (EC 2006). Dossiers are structured in sections (e.g., 'Ecotoxicological information') and sub-sections (e.g., ‘Aquatic toxicity Short-term toxicity to fish'), of which the latter contain the results of one or more ecotoxicity studies. Each reported data point presents a specified endpoint with its concentration value (e.g., EC50 = $15 \mathrm{mg} / \mathrm{L}$ ), complemented by additional information, such as test method and conditions, tested organisms and test duration. Focusing on freshwater ecosystems as currently most relevant aspect for characterizing ecotoxicity in various frameworks, we manually retrieved from the publicly available REACH dossiers (available on the official dissemination website of the European Chemicals Agency) all

This article is protected by copyright. All rights reserved. 
the information covering ecotoxicity studies with freshwater as stated water type as of June 2018.

To derive extrapolation factors for characterizing ecotoxicity for organic substances, based on highest quality aquatic ecotoxicological information covering various endpoints, exposure durations and species groups, we focused on experimental data for organic compounds with production/import volumes in Europe $>1000$ tonnes per year (Annex X), (EC 2006; Sobanska et al. 2014; Müller et al. 2017). This ensures that sufficient acute and chronic data are reported per chemical. Production/import volume is reported in the administrative data section of REACH dossiers. Mixtures, by-products and compounds defined as Unknown or Variable composition, Complex reaction products or Biological materials (UVCB) were excluded, based on reported substance type or manually where this information was missing. Data selection criteria were defined in a decision tree to obtain a high-quality dataset as input for extrapolations between endpoints and exposure durations, based on four main aspects. For each data point, the reported chemical should be uniquely allocated to a test material (aspect 1). The reported results should have a high assigned reliability (aspect 2), i.e., comply with data reporting requirements set out in standard test guidelines (Klimisch et al. 1997). The tested organisms should be specified to ensure a consistent definition of chemical-species combinations (aspect 3). Finally, test duration and exposure concentration should be reported with unambiguous units, and effect endpoints should follow a consistent terminology (aspect 4). If at least one of these aspects is not fulfilled, the respective data point is excluded from any further analysis.

This article is protected by copyright. All rights reserved. 


\section{Harmonization of selected data points}

After applying the criteria for data selection to all collected data points, there is a need for harmonization in terminology for expressing chemical, test species, endpoint, effect concentration and duration, and their units where applicable, before the selected data can be finally analyzed or used (Luechtefeld et al. 2016; Gustavsson et al. 2017; Müller et al. 2017). In Table 1, we provide an overview of the steps applied for harmonizing the reported data points into a consistent set of information that can be further analyzed. For example, in numerous cases, the tested species names were misspelled, or old nomenclature was applied, or no species was reported at all. Another required step is to categorize the exposure test duration as either 'acute' or 'chronic', to distinguish short-term vs. long-term endpoints, for which we used reported exposure test durations as starting point. REACH dossiers provide a general test duration classification only for fish and aquatic invertebrates (i.e., short-term and long-term toxicity), while also for these species groups misallocations were identified (Gustavsson et al. 2017). In support of this step, we applied a set of defined test duration thresholds for all considered species groups (see Table 1), to finally account for the influence of test duration on the extrapolation between different reported endpoints (Hahn et al. 2014). For algae and cyanobacteria, tests guidelines do not differentiate between acute and chronic effects and suggest an exposure duration of 72 hours, with measurements every 24 hours (OECD 2004; Hahn et al. 2014). However, due to the high reproduction rate (biomass doubles 78 times within 72 hours), we consider test outcomes with exposure beyond 1 day for these species groups to be chronic, as they cover the full life cycle of the test organisms. This is in line with previous findings (de Zwart 2002; Posthuma et al. 2019). This 
rendered almost all related data points for these microorganisms as chronic. In fact, despite their short duration, the algae ecotoxicological tests are in practice multigeneration tests.

\section{Deriving ecotoxicity extrapolation factors}

We retrieved 71343 data points from REACH dossiers, covering in total 1927 organic chemicals with an annual EU production/import volume of $\geq 1000$ tonnes. The main information retrieved for each data point was substance name (display name), CAS

number, EC number, nature of the study (type of information), test material, exposure duration, endpoint (dose descriptor), concentration tested (effect concentration), and species tested (test organism). In order to use these data for developing extrapolation factors, we applied the defined data selection criteria in an automated procedure to screen and pre-process each data point. This resulted in a largely reduced dataset containing data of high quality, which is required when deriving generalizable information from data analysis (Saouter et al. 2017a,b). In cases, where REACH data are to be used for other purposes (e.g., high-throughput risk screening of thousands of chemicals), less strict selection criteria might apply, allowing for yielding a larger set of data of lower average quality. Data pre-processing steps included the selection of experimental data (i.e., estimated or read-across data were disregarded), harmonization of reported information for species, exposure and endpoint (see Table 1), and the combination of endpoints (e.g., grouping of IC50-inhibitory concentration and LC50-lethal concentration into 'EC50', combining LOEC and EC10 into EC10 ${ }^{\mathrm{eq}}$, and NOEC and EC0 into NOEC, while disregarding other reported effect levels and ambiguous endpoints).

This article is protected by copyright. All rights reserved. 
From the pre-processed and harmonized high-quality dataset, extrapolation factors were then obtained from pairwise comparisons of the combination of endpoints (e.g., NOEC vs. EC50) and test duration levels (acute vs. chronic) for all chemicalspecies combinations where data for both endpoints and exposure duration levels were available. Regression analysis was then performed to test the correlation between the compared pairs across chemicals within each defined species group. Regressions were performed for all species groups with at least nine different tested chemical-species combinations to allow for robust interpretation. In addition, we propose generic extrapolation factors based on regressions in which we combined data across species groups. Endpoints considered in all regressions for acute and chronic exposure were NOEC, EC50, and a combined set of LOEC and EC10 that were merged and expressed as EC10-equivalents (EC10 ${ }^{\mathrm{eq}}$ ) as recently recommended starting point for calculating effect factors in LCIA (Owsianiak et al. 2019; Posthuma et al. 2019; Saouter et al. 2019a,b). We combined LOEC and EC10 for deriving extrapolation factors also from and toward EC10 ${ }^{\mathrm{eq}}$ as low-effect metric based on high uncertainties in the low range of species sensitivity distributions, rendering it difficult to treat LOEC and EC10 as separate metrics in statistical analyses (Iwasaki et al. 2015; King et al. 2017). Other endpoints are usually data-poor (see Table 2) and were hence not further analyzed. Regressions were conducted separately toward the three reference metrics that are commonly used in different assessment frameworks, namely $\mathrm{NOEC}_{\text {chronic }}, \mathrm{EC} 0_{\text {chronic }}$, and $\mathrm{EC} 10_{\text {chronic }}^{\mathrm{eq}}$.

\section{Addressing substances without ecotoxicity data}

In support of deriving extrapolation factors also for chemicals, for which no ecotoxicological information is reported at all, we also investigated whether there is any 
possible correlation between the reported effect data and octanol-water partitioning coefficients (Kow) for the reported chemicals. Several quantitative structure-activity relationships (QSAR) using Kow as main predictor have been developed in the past decades for estimating ecotoxicity effects for chemicals with a 'non-polar narcosis' mode of action (MOA). For example, Könemann (1981) was one of the first studies demostating a strong correlation between Kow and acute toxicity effects in fish, while Van Leeuwen et al. (1992) published QSARs for predicting NOECs for 19 aquatic species, and Ellison et al. (2008) developed a QSAR estimating toxicity in Tetrahymena pyriformis for regulatory purposes. However, as recently highlighted by Cronin (2017), still many challenges are present in developing reliable QSAR models for predicting expecially chronic ecotoxicity effects. We identified the MOA across chemicals using the open source application Toxtree (Patlewicz et al. 2008). Toxtree applies the Verhaar scheme (Verhaar et al. 1992; 2000), which groups organic compounds according to their MOA. For our analysis, we considered only compounds with 'non-polar narcosis' as MOA, since their ecotoxicity may be reliably predicted from lipophilicity (Vighi et al. 2009). For these compounds, we retrieved a respective set of consistent Kow values using the open source OPERA modeling suite that are based on about 15,000 curated and harmonized measurements (Mansouri et al. 2018). Linear regressions were then conducted for substances with $0 \leq \log$ Kow $\leq 6$, for which the Verhaar scheme is applicable (Kienzler et al. 2017).

This article is protected by copyright. All rights reserved. 
Results

Decision tree of data selection criteria and harmonization steps

Figure 1 presents the decision tree proposed for screening and harmonizing the large amount of information retrieved from REACH dossiers and building a high quality dataset for the subsequent extrapolation factor analysis. In the following, we describe how to apply the different data selection criteria and harmonization steps of the decision tree.

The first two steps of the data selection and harmonization method serve a proper identification of the collected data points in terms of considered chemical. In step 1 (chemical identifier), CAS registry number and EC number for the reported compound are checked and completed when missing, whereas in step 2 (test material) the reported compound is matched to the correct test material - in case of mismatch, the data point is disregarded. An example is cyclohexanone (CAS: 108-94-1), where data on short-term toxicity to algae and invertebrates refer to a structural analogue or surrogate substance. In this step, $75 \%$ of the reported data points were screened out for our purpose, because either tests were not run with the specified compound or the information about test material was missing. This might seem very restrictive; yet, less than $10 \%$ of the disregarded data points would have fulfilled the remaining data selection criteria, while of the data points that successfully passed step 2, 57\% also passed the subsequent criteria. Hence, applying a very restrictive criterion at the beginning of the entire data preprocessing method simplifies the subsequent steps by avoiding unnecessary harmonization and processing efforts.

This article is protected by copyright. All rights reserved. 
Next, the reliability of the ecotoxicological information was evaluated through the reported Klimisch score (Klimisch et al. 1997) in step 3 (study reliability). Of the remaining data points, $87 \%$ had reported scores of 1 (reliable without restriction) or 2 (reliable with restrictions), which were considered for further analysis. All other data were excluded. The study test type was used as subsequent data selection criterion in step 4 (nature of test), where we only considered experimental results for further analysis (91\% of the data passing step 3), while all estimated or calculated data points (e.g., QSARs, expert judgement, or read-across) were excluded. In step 5 (species name), the tested organisms' species names were spell-checked and harmonized with up-to-date nomenclatures. All data points with up-to-date or corrected species name (89\% of data passing step 4) were assigned to one of the pre-defined species groups in step 6 (species group) in order to allocate species group-specific exposure duration thresholds above which exposure is considered chronic in step 7 (acute/chronic exposure threshold). Even though a classification (grouping) of some of the tested species is already provided in $\mathrm{REACH}$, the step of systematically assigning a species group is considered important due to inconsistencies in the reported allocations, also discussed by Gustavsson et al. (2017). In step 8 (exposure duration), the reported exposure duration value and unit are checked and remaining data (i.e., 99.8\% of data points passing step 5) harmonized by converting them into a common unit (in our study, we used ‘days’ as common unit for reported exposure durations). Based on information from steps 6 to 8, we can categorize reported test results as 'chronic' or 'acute' in step 9 (exposure duration class). In step 10 (test concentration), reported test concentration value and unit are checked, and remaining data (i.e., $97 \%$ of data points passing step 8) harmonized by converting them into a

This article is protected by copyright. All rights reserved. 
common unit (in our study, we used 'mg/L' as common mass-based unit across reported test concentrations). Finally, the reported effect endpoints were checked in step 11 (effect endpoint) and remaining data (i.e., 84\% of data points passing step 10) harmonized by aggregating reported effect metrics into those that were selected for our study. In total, from all data points originally reported in REACH dossiers, $14.3 \%$ passed the set of strict data selection criteria to create a high quality dataset for further analysis.

When applying the decision tree presented in Figure 1 to the reported data, most of the data points were screened out due to insufficient or non-interpretable reported information. After harmonizing the remaining data, we yielded a high quality dataset containing 9627 data points for 1048 chemicals (54\% of the original set of chemicals), which we could further analyze. For each combination of species, endpoint and exposure duration, all reported data points were averaged per substance to account for the variability across and in-between reported toxicological test results. On average, 9 data points were ultimately available per chemical, where the chemical with the highest number of resulting data was 4,4’ isopropylidenediphenol (CAS RN: 80-05-7) with $n=96$ data points. Table 2 presents the summary statistics of the harmonized dataset after applying the data selection criteria. As expected, NOECs and acute EC50s are the predominant endpoints, representing respectively $44 \%$ and $38 \%$ of the final data, with a total contribution of acute data of 55\%, consistent with earlier findings (Fantke et al. 2018).

One of the reasons for the (slightly) higher availability of acute data as compared to chronic data is that REACH data are generated based on reporting requirements, with This article is protected by copyright. All rights reserved. 
chronic data only required for higher production/import volume chemicals. Further, acute tests are easier to conduct, faster and less expensive.

\section{Freshwater ecotoxicity extrapolation factors}

The final harmonized dataset was used to derive a consistent set of factors extrapolating between different effect endpoints and exposure durations. More specifically, we provide factors for extrapolating pairwise from acute and chronic NOEC, EC50 and EC10 ${ }^{\text {eq }}$ effect endpoints to $\mathrm{NOEC}_{\text {chronic }}$, $\mathrm{EC} 0_{\text {chronic }}$, and $\mathrm{EC} 10_{\text {chronic }}^{\mathrm{eq}}$ for use in different assessment frameworks. Extrapolating from acute tests will thereby show higher uncertainty than extrapolating from another chronic test, since different effect levels observed in the same test will correlate stronger than different effect levels reported from different tests. In Figure 2, we plot the effect concentrations (expressed in mg/L) across all chemical-species combinations for which at least one data point was reported for two compared endpoints. Where more than one data point was available per chemical-species combination, we plot the mean across data points with the variability across data points shown in error bars. Regressions were performed with free slope and with slope forced to unity per species group. For simplicity, only regression lines of the latter are shown in Figure 2 as colored dashed lines, since best fit slopes (free slopes) across regressions was always close to unity and usually within the $95 \%$ confidence interval (CI) range. For both regression types (free slope and slope equal to unity), we provide the coefficients of determination $\left(\mathrm{R}^{2}\right)$ and standard errors, showing that forcing the slope to unity does not influence the extrapolation results in most cases (see Table 3). An exception are invertebrates when extrapolating from acute to chronic endpoints, where the $\mathrm{R}^{2}$ decreased significantly when forcing the slope to unity. We furthermore tested the choice of

This article is protected by copyright. All rights reserved. 
grouping of EC10 and LOEC data points. Analyzing both endpoints separately yields similar regression results with no statistically significant difference between these endpoints (Supplemental Information (SI), Figure S1).

Due to data availability in REACH dossiers, only the three most representative species groups are considered in Figure 2 (i.e., algae/cyanobacteria, crustaceans and fish). Data for other species groups were insufficient to allow for robust regression (i.e., bacteria, invertebrates (non-crustaceans), vertebrates, and aquatic plants other than algae). Likewise, data points were insufficient to extrapolate from EC10 $0_{\text {acute }}^{\mathrm{eq}}$ for individual species groups. Generally, we did not derive any regression for a species group, whenever there were less than 10 chemical-species combinations available for any compared pair of endpoints.

As a general trend, robust correlations $\left(\mathrm{R}^{2}>0.85\right)$ were observed between two chronic or two acute endpoints, and between acute and chronic exposure for the same endpoint. Comparing any acute endpoint with another chronic endpoint yielded less good correlations $\left(\mathrm{R}^{2}<0.60\right)$. Goodness of fit ranged from $\mathrm{R}^{2}=0.95$ when extrapolating from acute to chronic EC50 for fish to $\mathrm{R}^{2}=0.30$ when extrapolating from acute NOEC to chronic $\mathrm{EC} 10^{\mathrm{eq}}$ for crustaceans. Weaker correlations are partly driven by common outliers (e.g., 2-(2H-benzotriazol-2-yl)-p-cresol, CAS: 2440-22-4). Some outliers had strong influence on the regressions, in line with findings from Posthuma et al. (2019), for example 4,4'-methylenedianiline (CAS: 101-77-9) influencing the regression from acute to chronic EC50 for crustaceans.

This article is protected by copyright. All rights reserved. 
Table 3 summarizes for each effect endpoint-exposure duration combination the derived extrapolation factors per species group, along with its regression statistics and 95\% confidence interval ranges, which are fundamentally important for correctly interpreting the variability around the proposed mean regression factors (Posthuma et al. 2019). Standard error and $\mathrm{R}^{2}$ are presented for both best-fit regressions and regressions with slope set to unity, to identify where the slope is significantly different from unity. Extrapolation factors for bacteria and invertebrates (non-crustaceans) could not be derived due to insufficient data points. For these species groups, we recommend applying generic extrapolation factors instead.

\section{Relevance of individual species groups}

Our species group-specific extrapolation factors do not show any significantly different trends in sensitivity toward chemical exposure across species groups, with a wide variability across data for all species groups and effect endpoints (Figure 3). This is in line with Figure 2, where sensitive species groups would be found predominantly toward the origins of the axes across plots, while less sensitive species groups would appear mostly far from the axes origins. However, none of the considered species groups shows such patterns.

To evaluate the distribution of sensitivities at the chemical level, we compared for acute and chronic EC50 the mean across data points for the same chemical and test species (Figure 4). We used EC50 as example effect endpoint with most available data 
points (44\%), and because the EC50 shows high robustness for testing the same chemical across species (Henderson et al. 2011).

Across substances with available data for acute EC50 (Figure 4, top), the two most represented species groups are crustaceans and fish. None of these shows a consistent trend of being more or less sensitive than any other included species group. This is partly due to the fact that the majority of the considered chemicals shows unspecific (“narcotic”) toxicity effects (Kienzler et al. 2017). If we would look at substances with more specific MOA, we would see that they are more toxic to certain species groups. An example are herbicides, which are most toxic to phototrophic microorganisms, exhibiting toxicity by disrupting photosynthesis (DeLorenzo et al. 2001). To identify such trends, however, requires to assess each chemical individually. As specific example, for 1,2-bis(prop-2-en-1-yl) benzene-1,2-dicarboxylate (CAS: 13117-9), the average acute EC50 across 4 crustaceans species is three order of magnitude lower than across 2 fish species, while for benzene-1,3-diamine (CAS: 108-45-2), the average acute EC50 across 6 crustaceans species is two order of magnitude higher than across 2 fish species. When analyzing chronic EC50 (Figure 4, bottom), we observe that crustaceans generally show a somewhat higher sensitivity to chemical exposure than algae/cyanobacteria and fish. Two exceptions are 1-(5,6,7,8-tetrahydro-3,5,5,6,8,8hexamethyl-2-naphthyl)ethan-1-one (CAS: 1506-02-1), and butane-1,3-diol (CAS: 10788-0), where fish species show higher sensitivity than other species groups. In general, for the different substances considered, crustaceans are more sensitive than fishes, which is in line with earlier findings (Müller et al. 2017).

This article is protected by copyright. All rights reserved. 


\section{Influence of octanol-water partitioning coefficient}

In order to support possible effect extrapolation for chemicals, for which no ecotoxicological information is available at all, we compared our curated ecotoxicity results against Kow for chemicals with 'non-polar narcosis' as MOA, for which lipophilicity can be used to predict ecotoxicity (Vighi et al. 2009). Curated data were grouped per species across effect endpoints and exposure durations, and endpoints considered at both acute and chronic exposure are EC50, NOEC and EC10 ${ }^{\mathrm{eq}}$. Results were plotted as inverse of the effect endpoint concentrations as function of Kow (Figure $5)$.

As a general trend, substances with high Kow are showing higher ecotoxicity potential (lower effect concentrations) across species, endpoints and exposure durations. However, numerous exceptions underline that Kow alone is usually a poor predictor for ecotoxicity. In Figure 5, we also provide regression equations for deriving ecotoxicity effect values from Kow for the three main studied effect endpoints and both exposure duration classes. We observe a clear shift of the regression lines from acute to chronic exposure across effect endpoints. Our ecotoxicity-Kow relationships are generally valid for non-reactive chemicals within certain solubility limits (Cronin 2017), and our dataset represents chemicals covering a wide range of physicochemical properties and toxicokinetics, tested with different species (Scholz et al. 2018). Hence, we recommend to only using these results for chemicals where no effect information is generally available to allow for assessing chemicals, which would otherwise not be considered in screening assessments.

This article is protected by copyright. All rights reserved. 


\section{Discussion}

\section{Recommendations for deriving ecotoxicity effect factors}

Table 4 summarizes ecotoxicity extrapolations factors for the nine studied effect endpoint-exposure duration combinations (simplified regressions with slope set to unity), and factors based on best-fit regressions. We recommend the species group generic extrapolation factors in Table 4 for use in large-scale screening studies where appropriate ecotoxicity data are lacking for various chemicals or not available across species groups. Whenever species group-specific information is available, we recommend using our factors presented in Table 3. For example, one could assume that no long-term ecotoxicological effect information is reported for thiram (CAS: 137-26-8), while only an $\mathrm{EC} 50_{\text {acute }}=1.6 \mathrm{mg} / \mathrm{L}$ for acute toxicity is reported for Lemna gibba. In such case, longterm toxicity can be derived by applying our recommended default extrapolation factor in Table 4 as $\mathrm{EC} 0_{\text {chronic }}=1.60 / 2=0.80 \mathrm{mg} / \mathrm{L}$, or by applying the best-fit factor as $\mathrm{EC}_{5} 0_{\text {chronic }}=(1.60)^{0.90} / 2.5=0.61 \mathrm{mg} / \mathrm{L}$. In cases where species group-specific extrapolations are possible or required, we recommend to apply factors from Table 3. For example, one could assume that long-term effects on fish are relevant, but no related information is available for the long-term ecotoxicological effects of p-phenylenediamine (CAS: 106-50-3). In such case, acute toxicity for Oncorhynchus mykiss reported as EC50 ${ }_{\text {acute }}=3.9 \mathrm{mg} / \mathrm{L}$ can be combined with our extrapolation factor for fish in Table 3, yielding an $\mathrm{EC} 0_{\text {chronic }}=3.9 / 1.71=2.28 \mathrm{mg} / \mathrm{L}$ (95\% CI: 1.73 to $\left.3.45 \mathrm{mg} / \mathrm{L}\right)$, or a $\mathrm{NOEC}_{\text {chronic }}=3.9 / 6.21=0.63 \mathrm{mg} / \mathrm{L}(95 \% \mathrm{CI}: 0.3$ to $1.34 \mathrm{mg} / \mathrm{L})$.

This article is protected by copyright. All rights reserved. 
Comparison of extrapolation factors with previous studies

We compared our default recommended generic extrapolation factors (Table 4) with previously published factors. Our proposed factor of 2 to extrapolate from acute to chronic EC50 is consistent with results obtained by Payet (2004) and de Zwart (2002), while being 30\% lower than the factor proposed by Posthuma et al. (2019). Our 95\% CI for this factor for specific species groups ranges from 0.6 to 4.5 (see Table 3). For NOEC, de Zwart (2002) and Posthuma et al. (2019) propose to apply a factor of 3 to extrapolate from acute to chronic effects, in line with our proposed factor of 3.1 (with species group 95\% CI ranging from 1.5 to 6.6). For extrapolating from chronic EC50 to NOEC, de Zwart (2002) and Posthuma et al. (2019) propose again a factor of 3, while Warne et al. (2015) proposes a factor of 5. Our default extrapolation factor is 3.3, with species group 95\% CI ranging from 2 to 5.8. For extrapolating from acute EC50 to chronic NOEC, Länge et al. (1998), Warne et al. (2015), Posthuma et al. (2019) and King et al. (2017) yield a factor between 8 and 10. Our proposed default factor is 5, with 95\% CI for specific species groups ranging from 0.8 to 13.1 . The high variability for this specific extrapolation factor is mainly driven by the uncertainty behind simultaneously extrapolating across endpoints and exposure duration classes. Finally, Warne et al. (2015) propose a factor of 2.5 to extrapolate from chronic LOEC to NOEC, which is slightly higher than our factor of 1.7 for extrapolating from chronic EC10 ${ }^{\mathrm{eq}}$ to NOEC, with $95 \%$ CI for specific species groups ranging from 0.8 to 2.3 .

We also compared our species group-specific factors with previous studies. For extrapolating acute EC50 to chronic NOEC, previous studies reported extrapolation factors between 8.9 and 12 for fish, between 6 and 10.9 for daphnia and 4.2 to 5.4 for

This article is protected by copyright. All rights reserved. 
algae (Länge et al. 1998; Ahlers et al. 2006; May et al. 2016; Kienzler et al. 2016; Saouter et al. 2019b). Our corresponding factors, which are based on a wide and diverse set of chemicals, are slightly lower with 6.2 for fish, 5.5 for crustaceans, and 2 for algae/cyanobacteria; however, our 95\% CI ranges encompass all previously reported factors (see Table 3). Saouter et al. (2019b) reported extrapolation factors from acute to chronic EC50 of 3.7 for fish and 5.4 for daphnia. Our corresponding factors are up to a factor of 2 smaller. Azimonti et al. (2015) yield factors for extrapolating from chronic EC50 and chronic EC10 to NOEC of, respectively, 4.3 to 4.9 and 1.1 to 1.5 across fish, daphnia and algae. Our corresponding factors are close to these values for both extrapolating from chronic EC50 and EC10 $0^{\mathrm{eq}}$.

While in some studies (e.g., Posthuma et al. 2019, Saouter et al. 2019b), NOEC and EC10 are combined due to their general strong correlation, we kept these two metrics separate, because the correlation varies largely across species groups (see Table 3) and because no-effect (NOEC) and effect (e.g., EC10 ${ }^{\mathrm{eq}}$ and EC50) are used in different assessment contexts. To our knowledge, extrapolation factors for our other effect endpoint-exposure duration combinations (e.g., chronic EC10 ${ }^{\mathrm{eq}}$ vs. EC50) have not been previously published. Overall, our results are consistent with previous studies, while indicating possible large differences across chemical-species combinations, and relying on high quality data for a much wider set of chemicals.

\section{Study limitations}

The retrieved REACH data went through a strict screening and selection process, in order to obtain a high quality pool of data on which our subsequent extrapolation factor analysis was based. Consequently, regressions obtained from the statistical

This article is protected by copyright. All rights reserved. 
analyses are based on a reliable dataset, well representing correlations between ecotoxicological data. However, there are several limitations related to differences between studied endpoints, and acute and chronic effects, available number of data points and species covered per chemical. When performing ecotoxicological tests with different levels of exposure for the same species group, diverse effects can be analyzed during the tests. For example, for fish, mortality is usually studied as effect in acute tests (OECD 1992), while growth is often studied in chronic tests (OECD 2012). This equally applies when pooling these different effects per endpoint, such as done in our study for e.g., NOEC (unspecified effect), NOErC (growth rate) and NOEbC (biomass production). To reduce uncertainty in individual factors, acute-to-chronic extrapolation should be analyzed at the level of individual chemicals, test species, and test conditions. Furthermore, we did not correct for any test repetitions or conditions (hardness, temperature, etc.) to reflect the actual diversity in testing environments, and usually pooled nominal and measured concentrations to avoid losing a large share of high-quality data (Saouter et al. 2019a). Finally, we did not account for the ecotoxicological mode of action of chemicals on the tested species, or other potentially relevant physicochemical properties of the tested compounds (e.g., solubility), which could have a high influence on the ecotoxicity test results and consequently on our extrapolation factors. However, given the conditions and data limitations of large-scale screening assessment frameworks, our proposed approach and related recommended factors constitute a robust mechanism to extrapolate across effect endpoints and exposure durations.

This article is protected by copyright. All rights reserved. 


\section{Kow-based ecotoxicity effect extrapolation}

We analyzed the correlation between the reported effect data and Kow for reported chemicals with 'non-polar narcosis' as MOA, with the aim of providing possible extrapolation for substances without available or reported ecotoxicological information. Overall, our Kow-ecotoxicity extrapolation corresponds well with earlier studies. As example, studies focusing on comparing acute EC50 in algae against Kow for a limited set of non-polar narcotics propose regressions of the general form $\log (1 / \mathrm{EC} 50)=\alpha \times$ $\log ($ Kow $)-\beta$ with regression coefficients similar to ours (Cronin et al. 2004; Hsieh et al. 2006; Tsai and Chen 2007). However, due to the high variability of the curated dataset and considering the general limitations of our study, we did not derive very robust Kowecotoxicity relationships. The proposed method for Kow-based ecotoxicity extrapolation is highly uncertain for the majority of the considered substances. Nevertheless, the clear shift between the acute and the chronic Kow-based regressions presented in Figure 5 suggests that there might be the potential for developing reliable models for predicting ecotoxicity effects for chemicals also with unspecified modes of action. As for the proposed extrapolations, considering other relevant physicochemical properties (e.g., solubility) and grouping the substances per specific MOA will likely yield more robust results. Yet, given limitations and constraints in accessibility of data for use in large-scale screening assessment frameworks, estimated ecotoxicity results extrapolated from Kow give a first indication of the magnitude of ecotoxicological effects in a comparative context when data that are more reliable are absent.

This article is protected by copyright. All rights reserved. 


\section{Future research needs}

From our first step toward developing species group-specific extrapolation factors and standardized curation methods for ecotoxicity information available on online databases such as the REACH-related, we derive various future research needs. First, after applying our decision tree, only $14 \%$ of the retrieved data were actually utilized for further analysis. On the one hand, when developing and building high quality datasets, strict and selective criteria need to be applied in order to keep only high quality and reliable data. On the other hand, more than $80 \%$ of the gathered data had to be disregarded, drastically limiting the potential of the high amount of ecotoxicity information available under REACH. In order to better exploit information reported under REACH as direct data source across various science and policy frameworks with their specific requirements for data quality, different and partly less restrictive data selection criteria should be defined, allowing the extrapolation of information also between chemicals (e.g., read-across, QSARs) to fill possible data gaps. This will enable the assessment of chemicals for which insufficient or no ecotoxicological information is currently available. Second, ecotoxicity data are reported mainly for three species groups under REACH. This implies the risk of giving more weight to certain species groups with higher data coverage (e.g., high amount of chronic data for algae/cyanobacteria) as compared to less represented species groups, which is relevant when assessing overall or average ecosystem pressure from chemicals, such as LCIA. In order to avoid such situations, data need to be reported across all relevant species groups, or weighting factors need to be derived for each species group, to ensure that also particularly sensitive species groups are represented. This is especially relevant for locations with unique 
ecosystem composition, such as tropical regions. Finally, the proposed decision tree has been developed on freshwater ecotoxicity data coming from REACH dossiers for organic chemicals. Applying our decision tree also to inorganic chemicals including metals requires to account for chemical species-specific aspects (Kirchhübel \& Fantke 2019). While our proposed curation method is generally applicable to develop extrapolation factors for organisms in other environments (e.g., sediment, marine water, and terrestrial environments) and using other data sources, our decision tree would have to be adapted to environment-specific aspects, species, and data source-specific reporting formats.

\section{Conclusions}

Ecotoxicity characterization requires a continuous improvement in line with the growing body of reported test results (e.g., in REACH) and marketed chemicals (Saouter et al. 2019a,b). Assessing ecological risk (in ERA) and life cycle impacts (in LCIA) of chemical emissions aims at supporting a high quality of our ecosystems , while improving the environmental sustainability performance of our product and service systems in line with policy goals and the global sustainable development agenda. Ultimately, we need to enable measuring progress toward reaching specific emission and ecological exposure reduction targets in support of the United Nations’ Sustainable Development Goals, the European Non-Toxic Environment strategy, and a sound and safe management of chemicals in the environment. For that, it will be necessary to benchmark characterized ecotoxicity impacts against optimal ecosystem health targets (Fantke and Illner 2019). Extrapolation factors for evaluating the ecotoxicity of the various marketed chemicals worldwide based on all available evidence, species, and tested endpoints provides a valuable contribution to developing and improving the 
required ecotoxicity characterization methods. While extrapolation factors have been developed earlier, we propose a consistent and robust set of factors for three relevant endpoints, for different species-groups and across species groups (generic factors), provide extrapolation from Kow for non-polar narcotic chemicals, where ecotoxicity test data are missing, and finally report uncertainty for our factors. With that, our extrapolation factors help that each assessment framework can use its specific ecotoxicity characterization metrics, while ensuring alignment across frameworks in terms of criteria for applying the same underlying test data and in terms of using the available evidence reported under the European REACH regulation.

\section{References}

Ahlers J, Riedhammer C, Vogliano M, Ebert RU, Kühne R, Schüürmann G. 2006. Acute to chronic ratios in aquatic toxicity - Variation across trophic levels and relationship with chemical structure. Environ Toxicol Chem. 25(11):2937-2945. doi:10.1897/05-701R.1.

Askham C. 2012. REACH and LCA---methodological approaches and challenges. Int J Life Cycle Assess. 17(1):43-57. doi:10.1007/s11367-011-0329-z.

Azimonti, G., Galimberti, F., Marchetto, F., Menaballi, L., Ullucci, S., Pellicioli, F., ... van der Voet, H. (2015). Comparison of NOEC values to EC10/EC20 values, including confidence intervals, in aquatic and terrestrial ecotoxicological risk assessment. EFSA Supporting Publications. EFSA supporting publication EN-906, Parma (It). doi:10.1126/scisignal.200411

Cesnaitis R, Sobanska MA, Versonnen B, Sobanski T, Bonnomet V, Tarazona J V., De Coen W. 2014. Analysis of the ecotoxicity data submitted within the framework of the REACH Regulation. Part 3. Experimental sediment toxicity assays. Sci Total Environ. 472:137-145. doi:10.1016/j.scitotenv.2013.10.059.

Cronin MTD. 2017. (Q)SARs to predict environmental toxicities: current status and 
future needs. Environ Sci Process Impacts. 19(3):213-220. doi:10.1039/C6EM00687F.

Cronin MTD, Netzeva TI, Dearden JC, Edwards R, Worgan ADP. 2004. Assessment and Modeling of the Toxicity of Organic Chemicals to Chlorella vulgaris: Development of a Novel Database. Chem Res Toxicol. 17(4):545-554. doi:10.1021/tx0342518.

DeLorenzo ME, Scott GI, Ross PE. 2001. Toxicity of pesticides to aquatic microorganisms: A review. Environ Toxicol Chem 20(1):84-98. doi:10.1002/etc.5620200108.

Dong Y, Gandhi N, Hauschild MZ. 2014. Development of Comparative Toxicity Potentials of 14 cationic metals in freshwater. Chemosphere. 112:26-33. doi:10.1016/j.chemosphere.2014.03.046.

EC European Commission. 2006. Regulation (EC) No 1907/2006 of the European Parliament and of the Council of 18 December 2006 concerning the Registration, Evaluation, Authorisation and Restriction of Chemicals (REACH).

ECHA. 2012. Guidance on Information Requirements and Chemical Safety Assessment Part E: Risk Characterisation. Eur Chem Agency. doi:10.2823/139408.

Ellison CM, Cronin MTD, Madden JC, Schultz TW. 2008. Definition of the structural domain of the baseline non-polar narcosis model for Tetrahymena pyriformis. In: SAR and QSAR in Environmental Research. 19(7-8):751-783.

doi:10.1080/10629360802550366

Fantke P, Aurisano N, Bare J, Backhaus T, Bulle C, Chapman PM, De Zwart D, Dwyer R, Ernstoff A, Golsteijn L, et al. 2018. Toward Harmonizing Ecotoxicity Characterization in Life Cycle Impact Assessment. Environ Toxicol Chem. 37(12):2955-2971. doi:10.1002/etc.4261.

Fantke P, Illner N. 2019. Goods that are good enough: Introducing an absolute sustainability perspective for managing chemicals in consumer products. Curr Opin Green Sustain Chem. 15:91-97. doi:https://doi.org/10.1016/j.cogsc.2018.12.001.

This article is protected by copyright. All rights reserved. 
Fantke P, Weber R, Scheringer M. 2015. From incremental to fundamental substitution in chemical alternatives assessment. Sustain Chem Pharm. 1:1-8.

doi:10.1016/j.scp.2015.08.001.

Guérit I, Bocquené G, James A, Thybaud E, Minier C. 2008. Environmental risk assessment: A critical approach of the European TGD in an in situ application. Ecotoxicol Environ Saf. 71(1):291-300. doi:10.1016/j.ecoenv.2008.01.020.

Gustavsson MB, Hellohf A, Backhaus T. 2017. Evaluating the environmental hazard of industrial chemicals from data collected during the REACH registration process. Sci Total 586:658-665. doi:10.1016/j.scitotenv.2017.02.039.

Hahn T, Diamond J, Dobson S, Howe P, Kielhorn J, Koennecker G, Lee-Steere C, Mangelsdorf I, Schneider U, Sugaya Y, et al. 2014. Predicted no effect concentration derivation as a significant source of variability in environmental hazard assessments of chemicals in aquatic systems: An international analysis. Integr Environ Assess Manag. 10(1):30-36. doi:10.1002/ieam.1473.

Henderson AD, Hauschild MZ, van de Meent D, Huijbregts MAJ, Larsen HF, Margni M, McKone TE, Payet J, Rosenbaum RK, Jolliet O. 2011. USEtox fate and ecotoxicity factors for comparative assessment of toxic emissions in life cycle analysis: sensitivity to key chemical properties. Int J Life Cycle Assess. 16(8):701. doi:10.1007/s11367-0110294-6.

Hsieh SH, Hsu CH, Tsai DY, Chen CY. 2006. Quantitative structure-activity relationships for toxicity of nonpolar narcotic chemicals to Pseudokirchneriella subcapitata. Environ Toxicol Chem. 25(11), 2920-2926. doi:10.1897/06-127R.1.

Igos E, Moeller R, Benetto E, Biwer A, Guiton M, Dieumegard P. 2014. Development of USEtox characterisation factors for dishwasher detergents using data made available under REACH. Chemosphere. 100(1907):160-166.

doi:10.1016/j.chemosphere.2013.11.041.

Iwasaki Y, Kotani K, Kashiwada S, Masunaga S. 2015. Does the Choice of NOEC or

This article is protected by copyright. All rights reserved. 
EC10 Affect the Hazardous Concentration for 5\% of the Species? Environ Sci Technol. 49(15):9326-9330. doi:10.1021/acs.est.5b02069.

Kienzler A, Halder M, Worth A. 2016. Scientific options for avoiding chronic fish testing on the basis of existing data and extrapolation approaches. Publications Office of the European Union, Luxembourg (Lu), ISBN 978-92-79-58167-0, doi:10.2788/546221.

Kienzler, A., Barron, M. G., Belanger, S. E., Beasley, A., \& Embry, M. R. (2017). Mode of action (MOA) assignment classifications for ecotoxicology: an evaluation of approaches. Environmental science \& technology. 51(17). doi: 10.1021/acs.est.7b02337.

King OC, Smith RA, Mann RM, Warne MSJ. 2017. Proposed aquatic ecosystem protection guideline values for pesticides commonly used in the Great Barrier Reef catchment area: Part 1 - 2,4-D, Ametryn, Diuron, Glyphosate, Hexazinone, Imazapic, Imidacloprid, Isoxaflutole, Metolachlor, Metribuzin, Metsulfur.

Kirchhübel, N., \& Fantke, P. (2019). Getting the chemicals right: Toward characterizing toxicity and ecotoxicity impacts of inorganic substances. Journal of Cleaner Production, 227, 554-565. doi: 10.1016/j.jclepro.2019.04.204.

Klimisch HJ, Andreae M, Tillmann U. 1997. A systematic approach for evaluating the quality of experimental toxicological and ecotoxicological data. Regul Toxicol Pharmacol. 25(1):1-5. doi:10.1006/rtph.1996.1076.

Könemann H. 1981. Quantitative structure-activity relationships in fish toxicity studies Part 1: Relationship for 50 industrial pollutants. Toxicology. 19(3):209-221. doi:10.1016/0300-483X(81)90130-X.

Länge R, Hutchinson TH, Scholz N, Solbé J. 1998. Analysis of the ECETOC Aquatic Toxicity (EAT) database. II - Comparison of acute to chronic ratios for various aquatic organisms and chemical substances. Chemosphere. 36(1):115-127. doi:10.1016/S00456535(97)10024-8.

Van Leeuwen CJ, Van Der Zandt PTJ, Aldenberg T, Verhaar HJM, Hermens JLM. 1992. Application of QSARs, extrapolation and equilibrium partitioning in aquatic effects

This article is protected by copyright. All rights reserved. 
assessment. I. Narcotic industrial pollutants. Environ Toxicol Chem. 11(2):267-282. doi:10.1002/etc.5620110216.

Lehmann D, Hoff D, Raimondo S, Pease A, Russom C, Steeger T. 2010. Predicting the Toxicities of Chemicals to Aquatic Animal Species. US Environ. Prot. Agency, Washington, DC. doi:10.13140/RG.2.1.1882.6002.

Luechtefeld T, Maertens A, Russo DP, Rovida C, Zhu H, Hartung T. 2016. Global analysis of publicly available safety data for 9,801 substances registered under REACH from 2008-2014. ALTEX. 33(2):95-109. doi:10.14573/altex.1510052.

Mansouri K, Grulke CM, Judson RS, Williams AJ. 2018. OPERA models for predicting physicochemical properties and environmental fate endpoints. J Cheminform. 10(1):10. doi:10.1186/s13321-018-0263-1.

May M, Drost W, Germer S, Juffernholz T, Hahn S. 2016. Evaluation of acute-to-chronic ratios of fish and Daphnia to predict acceptable no-effect levels. Environ Sci Eur. doi:10.1186/s12302-016-0084-7.

Mccarty LS, Borgert CJ, Posthuma L. 2018. The regulatory challenge of chemicals in the environment : Toxicity testing, risk assessment, and decision-making models. Regul Toxicol Pharmacol. 99(9):289-295. doi:10.1016/j.yrtph.2018.10.001.

Müller N, de Zwart D, Hauschild M, Kijko G, Fantke P. 2017. Exploring REACH as a potential data source for characterizing ecotoxicity in life cycle assessment. Environ Toxicol Chem. 36(2):492-500. doi:10.1002/etc.3542.

OECD. 1992. Test No. 203: Fish, Acute Toxicity Test, OECD Guidelines for the Testing of Chemicals, Section 2, OECD Publishing, Paris. doi:10.1787/9789264069961-en.

OECD. 2004. Test No. 201: Freshwater Alga and Cyanobacteria, Growth Inhibition Test. Organ Econ Coop Dev. doi:10.1787/9789264203785-en.

Owsianiak M, Fantke P, Posthuma L, Saouter E, Vijver M, Backhaus T, et al. 2019. Ecotoxicity impacts. In: Global Guidance on Environmental Life Cycle Impact

This article is protected by copyright. All rights reserved. 
Assessment Indicators - Volume 2, (Frischknecht R, Jolliet O, eds). Paris:

UNEP/SETAC Life Cycle Initiative.

http://usetox.org/download/UNEP_LCIA_V2_CH7_Proof.pdf

Patlewicz G, Jeliazkova N, Safford RJ, Worth AP, Aleksiev B. 2008. An evaluation of the implementation of the Cramer classification scheme in the Toxtree software. SAR QSAR Environ Res. 19(5-6), 495-524. doi:10.1080/10629360802083871.

Payet, J., 2004. Assessing toxic impacts on aquatic ecosystems in life cycle assessment (LCA). Institut des Sciences et Technologies de L'environment. Ecóle Polytechnique Fédérale de Lausanne, Lausanne, Switzerland, p. 232.

Posthuma L, van Gils J, Zijp MC, van de Meent D, de Zwartd D. 2019. Species sensitivity distributions for use in environmental protection, assessment, and management of aquatic ecosystems for 12386 chemicals. Environ Toxicol Chem. 38(4):905-917. doi:10.1002/etc.4373.

Raimondo S, Vivian DN, Barron MG. 2010. Web-based Interspecies Correlation Estimation ( Web-ICE ) for Acute Toxicity: User Manual v3.1. Office of Research and Development. US Environmental Protection Agency, Gulf Breeze, FL, USA. Epa/600/R$10 / 004$.

Rosenbaum RK. 2015. Ecotoxicity. In: Hauschild MZ, Huijbregts MAJ, editors. Life Cycle Impact Assessment. Dordrecht: Springer Netherlands. p. 139-162.

Saouter E, Aschberger K, Fantke P, Hauschild MZ, Bopp SK, Kienzler A, Paini A, Pant R, Secchi M, Sala S. 2017. Improving substance information in USEtox ${ }^{\circledR}$, part 1: Discussion on data and approaches for estimating freshwater ecotoxicity effect factors. Environ Toxicol Chem. 36(12):3450-3462. doi:10.1002/etc.3889.

Saouter E, Aschberger K, Fantke P, Hauschild MZ, Kienzler A, Paini A, Pant R, Radovnikovic A, Secchi M, Sala S. 2017. Improving substance information in USEtox®, part 2: Data for estimating fate and ecosystem exposure factors. Environ Toxicol Chem. 36(12):3463-3470. doi:10.1002/etc.3903.

This article is protected by copyright. All rights reserved. 
Saouter E, Biganzoli F, Pant R, Sala S, Versteeg D. 2019. Using REACH for the EU Environmental Footprint: building a usable ecotoxicity database (part I). Integr Environ Assess Manag. doi:10.1002/ieam.4168.

Saouter E, Wolff D, Biganzoli F, Versteeg D. 2019. Comparing options for deriving chemical ecotoxicity hazard values for the EU Environmental Footprint (part II). Integr Environ Assess Manag. doi:10.1002/ieam.4169.

Scholz S, Schreiber R, Armitage J, Mayer P, Escher BI, Lidzba A, Léonard M, Altenburger R. 2018. Meta-analysis of fish early life stage tests-Association of toxic ratios and acute-to-chronic ratios with modes of action. Environ Toxicol Chem. doi:10.1002/etc.4090.

Sobanska MA, Cesnaitis R, Sobanski T, Versonnen B, Bonnomet V, Tarazona J V., De Coen W. 2014. Analysis of the ecotoxicity data submitted within the framework of the REACH Regulation. Part 1. General overview and data availability for the first registration deadline. Sci Total Environ. 470-471:1225-1232.

doi:10.1016/j.scitotenv.2013.10.074.

Steingrímsdóttir MM, Petersen A, Fantke P. 2018. A screening framework for pesticide substitution in agriculture. J Clean Prod. 192:306-315.

doi:https://doi.org/10.1016/j.jclepro.2018.04.266.

Tarazona J V., Sobanska MA, Cesnaitis R, Sobanski T, Bonnomet V, Versonnen B, De Coen W. 2014. Analysis of the ecotoxicity data submitted within the framework of the REACH Regulation. Part 2. Experimental aquatic toxicity assays. Sci Total Environ. 472:137-145. doi:10.1016/j.scitotenv.2013.10.073.

Tsai KP, Chen CY. 2007. An algal toxicity database of organic toxicants derived by a closed-system technique. Environ Toxicol Chem. 26(9):1931-1939. doi:10.1897/06612R.1.

Verhaar HJM, van Leeuwen CJ, Hermens JLM. 1992. Classifying environmental pollutants. Chemosphere. 25(4):471-491. doi:10.1016/0045-6535(92)90280-5.

This article is protected by copyright. All rights reserved. 
Verhaar HJM, Solbé J, Speksnijder J, Van Leeuwen CJ, Hermens JLM. 2000. Classifying environmental pollutants: Part 3. External validation of the classification system. Chemosphere. 40(8):875-883. doi:10.1016/S0045-6535(99)00317-3.

Versonnen B, Tarazona J V., Cesnaitis R, Sobanska MA, Sobanski T, Bonnomet V, De Coen W. 2014. Analysis of the ecotoxicity data submitted within the framework of the REACH Regulation. Part 4. Experimental terrestrial toxicity assays. Sci Total Environ. 475:123-131. doi:10.1016/j.scitotenv.2013.10.058.

Vighi M, Migliorati S, Monti GS. 2009. Toxicity on the luminescent bacterium Vibrio fischeri (Beijerinck). I: QSAR equation for narcotics and polar narcotics. Ecotoxicol Environ Saf. 72(1):154-161. doi:10.1016/j.ecoenv.2008.05.008.

Warne Ms, Batley G, van Dam R, Chapman J, Fox D, Hickey C, Stauber J. 2015. Revised Method for Deriving Australian and New Zealand Water Quality Guideline Values for Toxicants. Prepared for the Council of Australian Government's Standing Council on Environment and Water (SCEW). Department of Science. Information Technology and Innovation, Brisbane, Queensland.

de Zwart D. 2002. Observed Regularities in Species Sensitivity Distributions for Aquatic Species. In: Species Sensitivity Distributions in Ecotoxicology. CRC Press. p. 157-178.

This article is protected by copyright. All rights reserved. 
Figures

Figure 1. Decision tree containing data selection criteria (boxes with yes/no option) and harmonization steps applied to the retrieved freshwater ecotoxicological

REACH dossiers for obtaining a high quality harmonized dataset as starting point for data analysis.

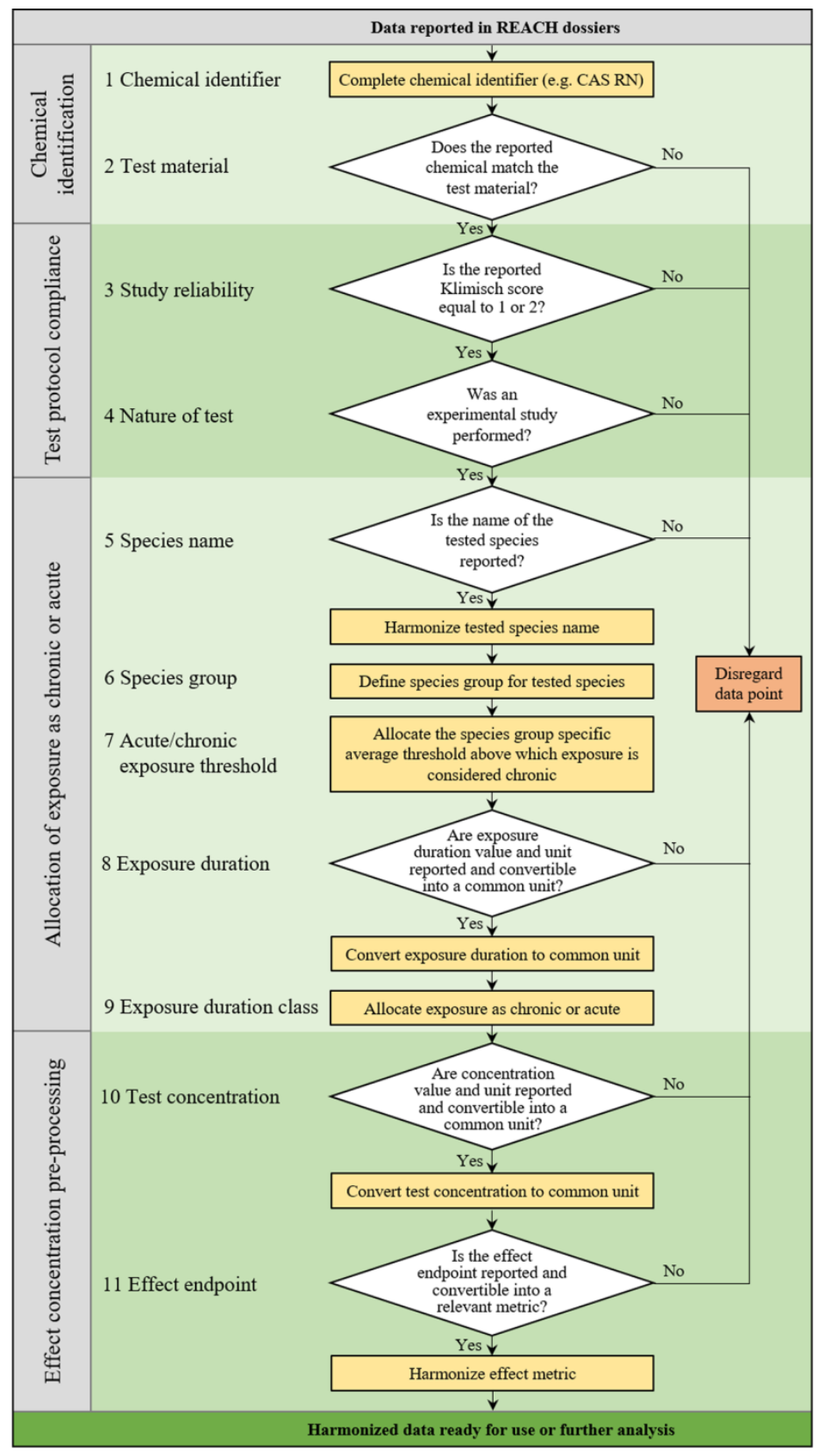

This article is protected by copyright. All rights reserved. 
Figure 2. Pairwise comparison of different ecotoxicological effect endpoints (NOEC, EC50, and $\mathrm{EC}^{\mathrm{eq}}{ }^{\mathrm{eq}}$ ) and exposure duration classes (acute and chronic) for different species groups. White dashed lines represent 1:1 lines, and colored dashed lines represent species group-specific regression lines with unity slope, with regression line colors matching data point colors. Colored plot axes represent the endpoints toward which the calculation of an extrapolation factor was conducted, namely toward NOEC chronic $_{\text {(left-side plots), EC50 }}$ chronic (middle plots), and EC10 chronic $_{\text {eq }}$ (right-side plots).
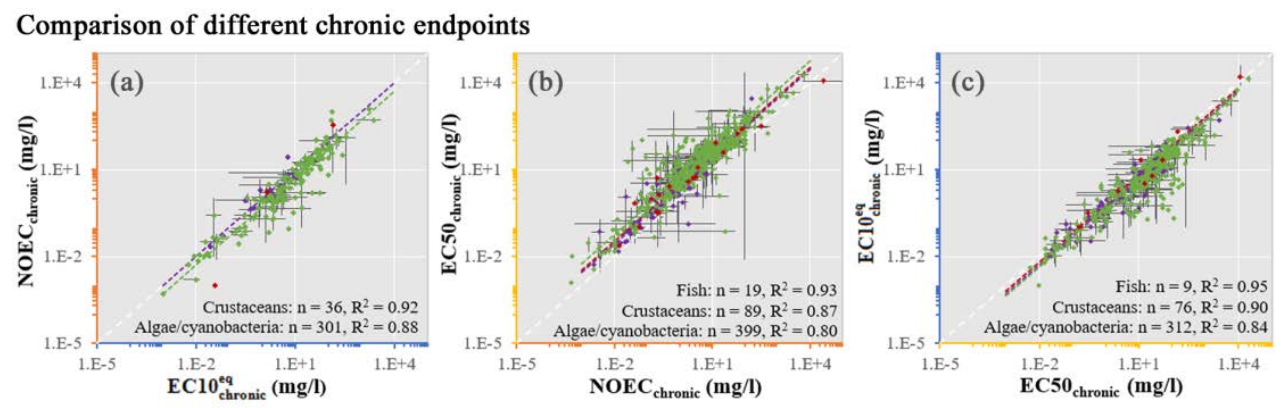

Comparison of acute and chronic endpoints
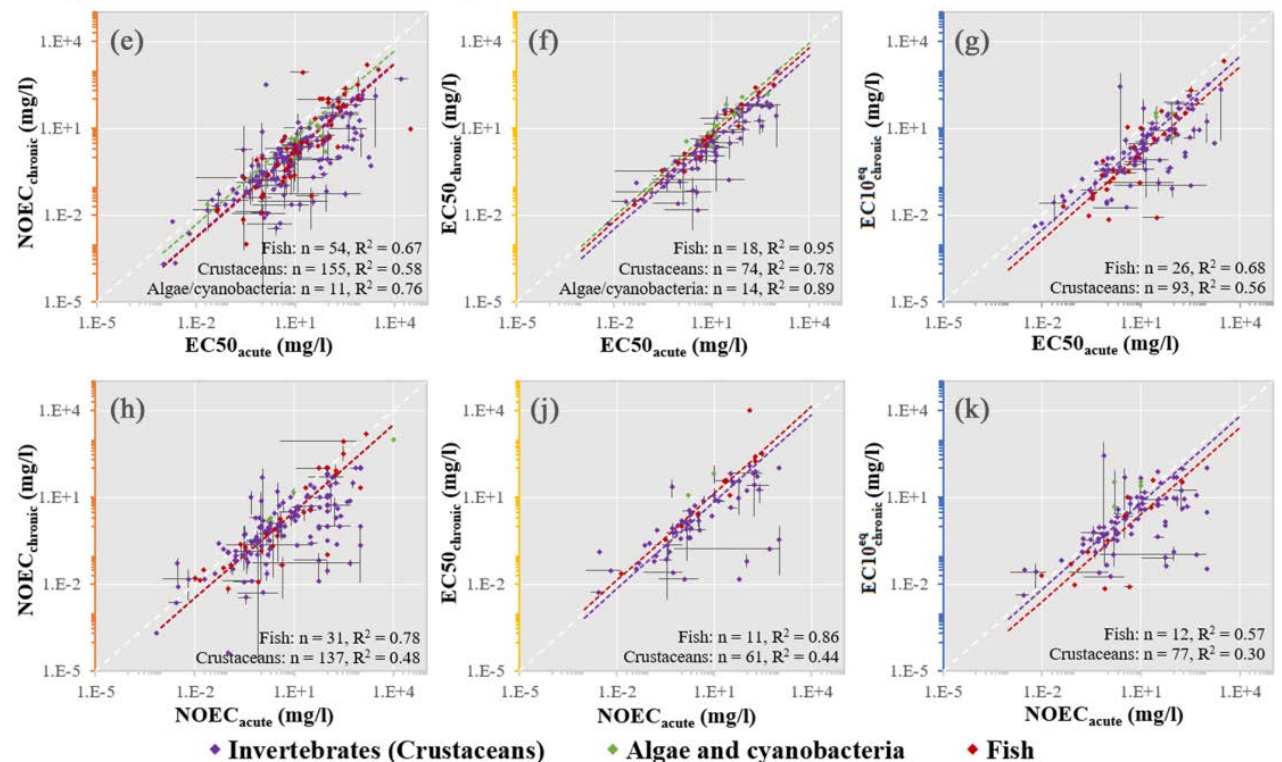

This article is protected by copyright. All rights reserved. 
Figure 3. Variability of acute and chronic EC50 (top) and NOEC (bottom) data points for different species groups. “Other” includes aquatic invertebrates (noncrustaceans), aquatic vertebrates and aquatic plants other than algae.

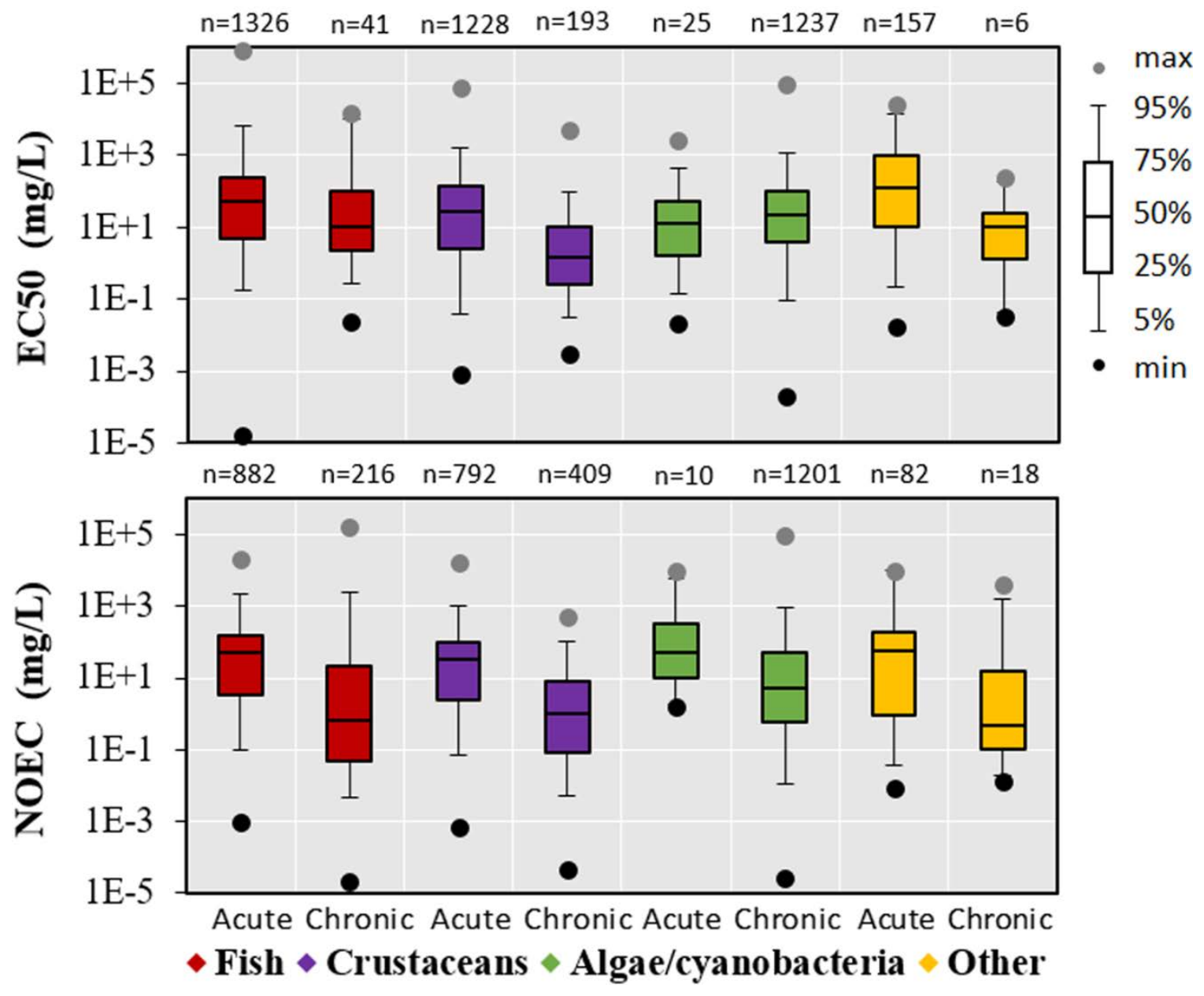

This article is protected by copyright. All rights reserved. 
Figure 4. Mean acute and chronic EC50 across harmonized data points per chemical, grouped according to different species groups and ranked by increasing sensitivity of crustaceans, with 448 (fish), 435 (crustaceans) and 15 (algae/cyanobacteria) acute and 24 (fish), 87 (crustaceans) and 92 (algae/cyanobacteria) chronic data. “Other” includes aquatic invertebrates (noncrustaceans), aquatic vertebrates and aquatic plants other than algae.
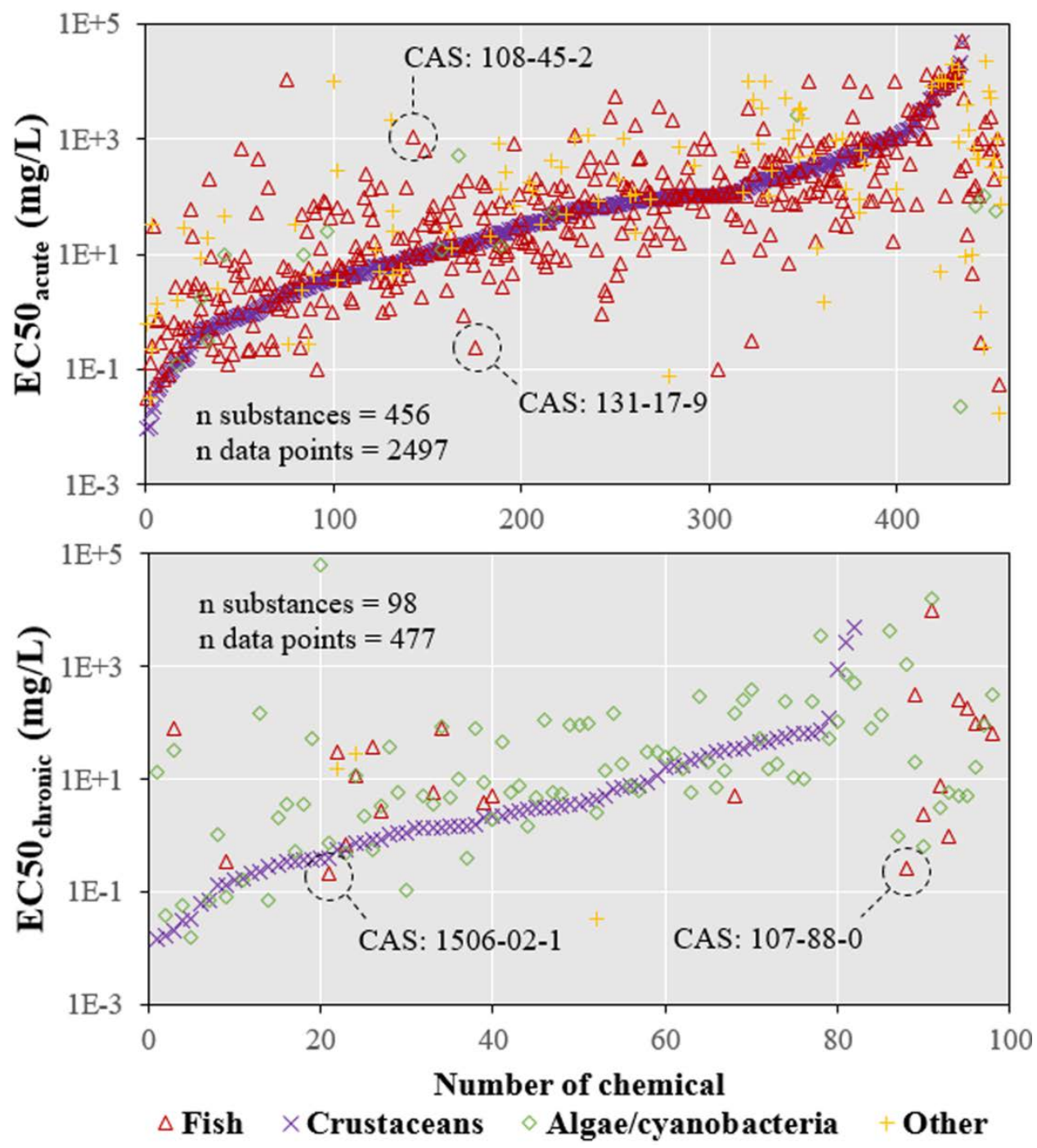

This article is protected by copyright. All rights reserved. 
Figure 5. Correlation between EC50, EC10 ${ }^{\mathrm{eq}}$ and NOEC ( $y$-axis) and Kow ( $x$-axis) for chemicals with a 'non-polar narcosis' mode of action. Regression equations are presented separately for acute and chronic data, along with their respective underlying number of data points and $\mathrm{R}^{2}$.

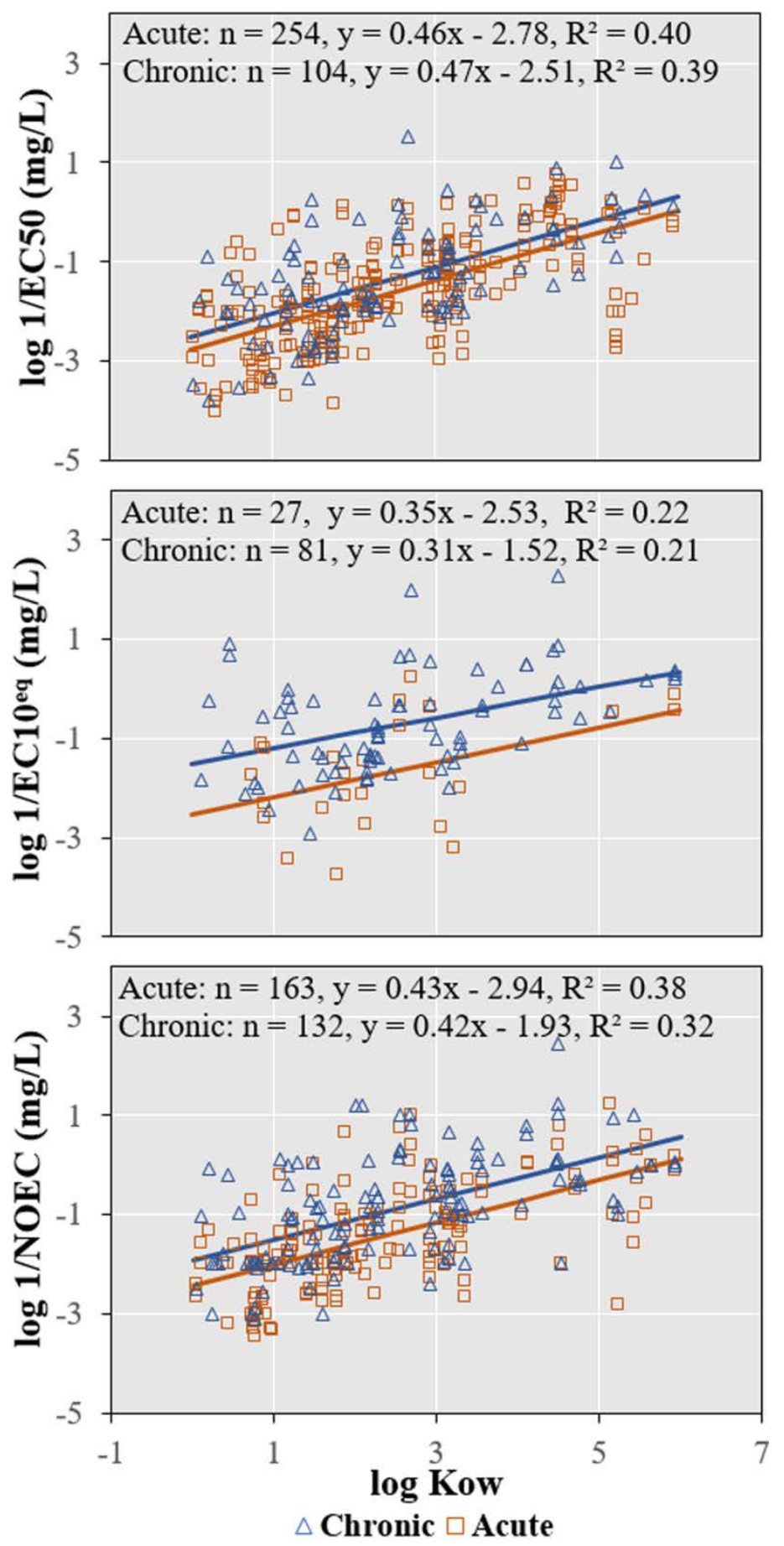

This article is protected by copyright. All rights reserved. 
Table 1. Overview of applied steps for harmonizing reported ecotoxicity information, with examples provided for each step

\begin{tabular}{|c|c|c|}
\hline Aspect & Harmonization steps & Examples \\
\hline $\begin{array}{l}\text { Chemical } \\
\text { identifier }\end{array}$ & $\begin{array}{l}\text { Complete for each data point the latest } \\
\text { CAS registry number when missing }\end{array}$ & $\begin{array}{l}\text { Missing CAS registry } \\
\text { number '1680-31-5’ } \\
\text { assigned to 'dioctyl } \\
\text { carbonate’ (EC number: } \\
\text { 434-850-2) }\end{array}$ \\
\hline Species name & $\begin{array}{l}\text { Conversion to latest official species } \\
\text { names }^{(b)}\end{array}$ & $\begin{array}{l}\text { 'Brachydanio rerio' (old } \\
\text { name) changed to 'Danio } \\
\text { rerio' }\end{array}$ \\
\hline Species group & $\begin{array}{l}\text { Allocation of tested species to the } \\
\text { relevant species group (i.e., algae, } \\
\text { cyanobacteria and microorganism, } \\
\text { invertebrates (crustaceans), fish, } \\
\text { invertebrates (non-crustaceans), } \\
\text { vertebrates and aquatic plants other than }^{(\text {algae) }}{ }^{(b)}\end{array}$ & $\begin{array}{l}\text { 'Daphnia magna' allocated } \\
\text { to 'invertebrates } \\
\text { (crustaceans)'; 'Danio rerio' } \\
\text { allocated to 'fish' }\end{array}$ \\
\hline $\begin{array}{l}\text { Exposure } \\
\text { duration }\end{array}$ & $\begin{array}{l}\text { Conversion of exposure duration values } \\
\text { into common unit (e.g., using 'days’ as } \\
\text { common unit) }\end{array}$ & $\begin{array}{l}\text { ' } 48 \text { hours' of exposure } \\
\text { converted to ' } 2 \text { days' }\end{array}$ \\
\hline $\begin{array}{l}\text { Effect } \\
\text { concentration }\end{array}$ & $\begin{array}{l}\text { Effect concentration values converted } \\
\text { into consistent unit (e.g., using 'mg/L' as } \\
\text { common unit) }\end{array}$ & $\begin{array}{l}\text { '0.02 g/L’ converted to '20 } \\
\mathrm{mg} / \mathrm{L} \text { ' }\end{array}$ \\
\hline $\begin{array}{l}\text { Exposure } \\
\text { duration type }\end{array}$ & $\begin{array}{l}\text { Allocation of exposure duration to } \\
\text { exposure duration type (acute vs. } \\
\text { chronic); acute } \leq 1 \text { day for algae, } \\
\text { cyanobacteria and microorganism, } \leq 4 \\
\text { days for invertebrates (crustaceans) and } \leq \\
7 \text { days for fishes, invertebrates (non- }\end{array}$ & $\begin{array}{l}\text { Exposure of Daphnia magna } \\
\text { (crustaceans) of } 4 \text { days } \\
\text { allocated as 'acute'; } \\
\text { exposure of Danio rerio } \\
\text { (fishes) of } 21 \text { days allocated }\end{array}$ \\
\hline
\end{tabular}

This article is protected by copyright. All rights reserved. 


\begin{tabular}{|l|l|l|}
\hline & $\begin{array}{l}\text { crustaceans), vertebrates and aquatic } \\
\text { plants other than algae }\end{array}$ & as 'chronic' \\
\hline Endpoint & $\begin{array}{l}\text { Harmonization and aggregation of } \\
\text { endpoints; EC0, EL0, IC0, LC0, } \\
\text { NOAEC, NOEC, NOEbC, NOErC, } \\
\text { NOEL grouped into NOEC; EC10, IC10, } \\
\text { LC10, LOEC grouped into EC10 } \\
\text { EC50, EbC50, EbL50, ErC50, ErL50, } \\
\text { IC50, LC50 grouped into EC50 }\end{array}$ & $\begin{array}{l}\text { 'NOErC' changed to } \\
\text { 'NOEC'; 'EC0' changed to }\end{array}$ \\
\hline
\end{tabular}

(a) Official chemical databases (e.g. U.S. Environmental Protection Agency’s Chemistry Dashboard, comptox.epa.gov/dashboard)

(b) Official species lists (e.g. International Union for Conservation of Nature and Natural Resources' species lists, www.iucnredlist.org)

(c) de Zwart (2002), Payet (2005), Müller et al. (2017), King et al. (2017), Posthuma et al. (2019)

NOEC $=$ No-Observed Effect Concentration

Table 2. Overview of the distribution of harmonized ecotoxicity data points (count) across species groups and effect endpoints

\begin{tabular}{lcccccccccccc}
\multicolumn{1}{l}{ Endpoint } & NOEC & LOEC & EC10 & EC50 & ECother & Total \\
Species Group | Exposure duration & Acute Chronic Acute Chronic Acute Chronic Acute Chronic Acute Chronic \\
Algae and cyanobacteria & 10 & 1201 & 4 & 202 & 2 & 423 & 25 & 1237 & 5 & 161 & 3270 \\
Aquatic plants other than algae & 19 & - & 3 & - & 7 & 1 & 16 & 5 & 2 & - & 53 \\
Bacteria & 37 & 4 & 1 & - & 81 & - & 93 & - & 43 & 1 & 260 \\
Fish & 882 & 216 & 36 & 53 & 14 & 4 & 1326 & 41 & 245 & 3 & 2820 \\
Invertebrates (crustaceans) & 792 & 409 & 41 & 141 & 51 & 40 & 1228 & 193 & 217 & 11 & 3123 \\
Invertebrates (non-crustaceans) & 25 & 11 & - & 3 & - & - & 44 & 1 & 8 & - & 92 \\
Vertebrates & 1 & 3 & 1 & - & - & - & 4 & - & - & - & 9
\end{tabular}

This article is protected by copyright. All rights reserved. 
Total

$\begin{array}{lllllllllll}1766 & 1844 & 86 & 399 & 155 & 468 & 2736 & 1477 & 520 & 176 & 9627\end{array}$

NOEC $=$ No-Observed Effect Concentration; LOEC $=$ Lowest Observed Effect

Concentration; EC10 = Effect concentration inducing a 10\% response over background;

EC50 = Effect concentration inducing a 50\% response over background; ECother =

Effect concentration inducing a given response over background, grouping all remaining reported EC data points (i.e., EC20, EC25, EC75, EC100)

Table 3. Extrapolation factors and $95 \%$ confidence interval (CI) ranges per species group for different ecotoxicological effect endpoint-exposure duration combinations, including regression statistics for best-fit regressions, and for regression with slope set to unity

\begin{tabular}{|c|c|c|c|c|c|c|c|c|c|}
\hline $\begin{array}{l}\text { Extrapolation } \\
\text { between } \\
\text { endpoints* }\end{array}$ & $\begin{array}{l}\text { Species } \\
\text { group }\end{array}$ & $\begin{array}{l}\text { Extrapolation } \\
\text { factor = } \\
1 / \mathbf{1 0}^{\text {intercept }} \\
\\
(95 \% \mathrm{CI})\end{array}$ & $\begin{array}{l}\text { Data } \\
\text { points** }\end{array}$ & $\begin{array}{l}\text { Intercept } \\
\\
(95 \% \\
\text { CI })\end{array}$ & $\begin{array}{l}\text { Slope } \\
(95 \% \mathrm{CI})\end{array}$ & $\begin{array}{l}\text { Standard } \\
\text { error }\end{array}$ & $\begin{array}{l}\begin{array}{l}\text { Standard } \\
\text { error, }\end{array} \\
\text { slope }=1\end{array}$ & $\mathbf{R}^{2}$ & $\begin{array}{l}\mathbf{R}^{2}, \\
\text { slope } \\
=1\end{array}$ \\
\hline \multirow[t]{3}{*}{$\begin{array}{l}\text { to } \mathrm{EC} 50_{\text {chronic }} \\
\text { from EC50 acute }\end{array}$} & Fish & $\begin{array}{l}1.71 \\
\text { (1.13 to } 2.58)\end{array}$ & $\begin{array}{l}n=18 \\
n_{y}=23 \\
n_{x}=44\end{array}$ & $\begin{array}{l}-0.233 \\
(-0.41 \text { to } \\
-0,06) \\
\end{array}$ & $\begin{array}{l}1.002 \\
(0.88 \text { to } \\
1.12)\end{array}$ & 0.258 & 0.258 & 0.953 & 0.953 \\
\hline & Invertebrates & $\begin{array}{l}3.14 \\
(2.20 \text { to } 4.48)\end{array}$ & $\begin{array}{l}n=74 \\
n_{y}=147 \\
n_{x}=186\end{array}$ & $\begin{array}{l}-0.496 \\
(-0.65 \text { to } \\
-0.34) \\
\end{array}$ & $\begin{array}{l}0.850 \\
\\
(0.74 \text { to } \\
0.96)\end{array}$ & 0.532 & 0.575 & $\mid 0.775$ & 0.736 \\
\hline & $\begin{array}{l}\text { Algae and } \\
\text { bacteria }\end{array}$ & $\begin{array}{l}1.14 \\
\text { (0.57 to } 2.29)\end{array}$ & $\begin{array}{l}n=14 \\
n_{y}=35 \\
n_{x}=17\end{array}$ & $\begin{array}{l}-0.056 \\
\\
(-0.36 \text { to } \\
0.26)\end{array}$ & $\begin{array}{l}0.938 \\
\\
(0.73 \text { to } \\
1.15)\end{array}$ & 0.300 & 0.315 & 0.888 & 0.876 \\
\hline \multirow[t]{2}{*}{$\begin{array}{l}\text { to } \mathrm{EC} 0_{\text {chronic }} \\
\text { from } \\
\text { NOEC }_{\text {chronic }}\end{array}$} & Fish & $\begin{array}{l}0.31 \\
(0.20 \text { to } 0.47)\end{array}$ & $\begin{array}{l}n=19 \\
n_{y}=26 \\
n_{x}=38\end{array}$ & $\begin{array}{l}0.513 \\
(0.33 \text { to } \\
0.70) \\
\end{array}$ & $\begin{array}{l}0.863 \\
\\
(0.74 \text { to } \\
0.98)\end{array}$ & 0.371 & 0.434 & 0.933 & 0.908 \\
\hline & Invertebrates & $\begin{array}{l}0.36 \\
(0.30 \text { to } 0.44)\end{array}$ & $\begin{array}{l}n=89 \\
n_{y}=173\end{array}$ & $\begin{array}{l}0.441 \\
(0.35 \text { to }\end{array}$ & $\begin{array}{l}0.950 \\
0.87 \text { to }\end{array}$ & 0.413 & 0.417 & 0.870 & 0.867 \\
\hline
\end{tabular}

This article is protected by copyright. All rights reserved. 


\begin{tabular}{|c|c|c|c|c|c|c|c|c|c|}
\hline $\begin{array}{l}\text { Extrapolation } \\
\text { between } \\
\text { endpoints* }\end{array}$ & $\begin{array}{l}\text { Species } \\
\text { group }\end{array}$ & $\begin{array}{l}\text { Extrapolation } \\
\text { factor = } \\
1 / 10^{\text {intercept }} \\
\\
(95 \% \text { CI })\end{array}$ & $\begin{array}{l}\text { Data } \\
\text { points** }\end{array}$ & $\begin{array}{l}\text { Intercept } \\
(95 \% \\
\text { CI })\end{array}$ & $\begin{array}{l}\text { Slope } \\
(95 \% \text { CI })\end{array}$ & $\begin{array}{l}\text { Standard } \\
\text { error }\end{array}$ & $\begin{array}{l}\begin{array}{l}\text { Standard } \\
\text { error, }\end{array} \\
\text { slope }=1\end{array}$ & $\mathbf{R}^{2}$ & $\begin{array}{l}\mathbf{R}^{2} \\
\text { slope } \\
=1\end{array}$ \\
\hline & & & $n_{x}=168$ & $0.53)$ & 1.03) & & & & \\
\hline & $\begin{array}{l}\text { Algae and } \\
\text { bacteria }\end{array}$ & $\begin{array}{l}0.18 \\
(0.16 \text { to } 0.20)\end{array}$ & $\begin{array}{l}n=399 \\
n_{y}=881 \\
n_{x}=763\end{array}$ & $\begin{array}{l}0.748 \\
(0.70 \text { to } \\
0.80)\end{array}$ & $\begin{array}{l}0.857 \\
(0.82 \text { to } \\
0.90)\end{array}$ & 0.492 & 0.524 & 0.800 & 0.773 \\
\hline \multirow[t]{2}{*}{$\begin{array}{l}\text { to } \mathrm{EC} 50_{\text {chronic }} \\
\text { from } \\
\text { NOEC }_{\text {acute }}\end{array}$} & Fish & $\begin{array}{l}0.75 \\
(0.22 \text { to } 2.59)\end{array}$ & $\begin{array}{l}n=11 \\
n_{y}=15 \\
n_{x}=12\end{array}$ & $\begin{array}{l}0.126 \\
(-0.41 \text { to } \\
0.66)\end{array}$ & $\begin{array}{l}1.08 \\
(0.76 \text { to } \\
1.4)\end{array}$ & 0.618 & 0.636 & 0.864 & 0.855 \\
\hline & Invertebrates & $\begin{array}{l}1.43 \\
(0.85 \text { to } 2.41)\end{array}$ & $\begin{array}{l}n=61 \\
n_{y}=120 \\
n_{x}=106\end{array}$ & $\begin{array}{l}-0.15 \\
(-0.38 \text { to } \\
0.07)\end{array}$ & $\begin{array}{l}0.558 \\
(0.40 \text { to } \\
0.72)\end{array}$ & 0.824 & 1.032 & 0.440 & 0.122 \\
\hline \multirow[t]{3}{*}{$\begin{array}{l}\text { to } \mathrm{EC} 50_{\text {chronic }} \\
\text { from } \\
\text { EC10 } \\
\text { chronic }\end{array}$} & Fish & $\begin{array}{l}0.32 \\
(0.16 \text { to } 0.62)\end{array}$ & $\begin{array}{l}n=9 \\
n_{y}=14 \\
n_{x}=15\end{array}$ & $\begin{array}{l}0.50 \\
(0.21 \text { to } \\
0.76)\end{array}$ & $\begin{array}{l}0.867 \\
(0.69 \text { to } \\
1.04)\end{array}$ & 0.347 & 0.428 & 0.952 & 0.927 \\
\hline & Invertebrates & $\begin{array}{l}0.65 \\
(0.53 \text { to } 0.80)\end{array}$ & $\begin{array}{l}n=76 \\
n_{y}=149 \\
n_{x}=109\end{array}$ & $\begin{array}{l}0.190 \\
(0.10 \text { to } \\
0.28)\end{array}$ & $\begin{array}{l}0.978 \\
(0.90 \text { to } \\
1.06)\end{array}$ & 0.394 & 0.395 & 0.843 & 0.802 \\
\hline & $\begin{array}{l}\text { Algae and } \\
\text { bacteria }\end{array}$ & $\begin{array}{l}0.27 \\
(0.23 \text { to } 0.30)\end{array}$ & $\begin{array}{l}n=312 \\
n_{y}=656 \\
n_{x}=564\end{array}$ & $\begin{array}{l}0.58 \\
(0.52 \text { to } \\
0.63)\end{array}$ & $\begin{array}{l}0.899 \\
(0.86 \text { to } \\
0.94)\end{array}$ & 0.425 & 0.450 & 0.836 & 0.809 \\
\hline \multirow[t]{2}{*}{$\begin{array}{l}\text { to } \mathrm{NOEC}_{\text {chronic }} \\
\text { from EC } 50_{\text {acute }}\end{array}$} & Fish & $\begin{array}{l}6.21 \\
(2.92 \text { to } 13.17)\end{array}$ & $\begin{array}{l}n=54 \\
n_{y}=112 \\
n_{x}=91\end{array}$ & $\begin{array}{l}-0.7927 \\
(-1.12 \text { to } \\
-0.47)\end{array}$ & $\begin{array}{l}0.99 \\
(0.79 \text { to } \\
1.18)\end{array}$ & 0.841 & 0.841 & 0.670 & 0.669 \\
\hline & Invertebrates & $\begin{array}{l}5.53 \\
\text { (3.84 to } 7.97)\end{array}$ & $\begin{array}{l}n=155 \\
n_{y}=266 \\
n_{x}=343\end{array}$ & $\begin{array}{l}-0.743 \\
(-0.90 \text { to } \\
-0.58)\end{array}$ & $\begin{array}{l}0.706 \\
(0.61 \text { to } \\
0.80)\end{array}$ & 0.775 & 0.918 & 0.582 & 0.414 \\
\hline
\end{tabular}

This article is protected by copyright. All rights reserved. 


\begin{tabular}{|c|c|c|c|c|c|c|c|c|c|}
\hline $\begin{array}{l}\text { Extrapolation } \\
\text { between } \\
\text { endpoints* }\end{array}$ & $\begin{array}{l}\text { Species } \\
\text { group }\end{array}$ & $\begin{array}{l}\text { Extrapolation } \\
\text { factor }= \\
1 / 10^{\text {intercept }} \\
\\
(95 \% \text { CI })\end{array}$ & $\begin{array}{l}\text { Data } \\
\text { points** }\end{array}$ & $\begin{array}{l}\text { Intercept } \\
(95 \% \\
\text { CI })\end{array}$ & $\begin{array}{l}\text { Slope } \\
\text { (95\% CI) }\end{array}$ & $\begin{array}{l}\text { Standard } \\
\text { error }\end{array}$ & $\begin{array}{l}\begin{array}{l}\text { Standard } \\
\text { error, }\end{array} \\
\text { slope }=1\end{array}$ & $\mathbf{R}^{2}$ & $\begin{array}{l}\mathbf{R}^{2} \\
\text { slope } \\
=1\end{array}$ \\
\hline & $\begin{array}{l}\text { Algae and } \\
\text { bacteria }\end{array}$ & $\begin{array}{l}2.04 \\
(0.76 \text { to } 5.50)\end{array}$ & $\begin{array}{l}n=11 \\
n_{y}=24 \\
n_{x}=12\end{array}$ & $\begin{array}{l}-0.309 \\
(-0.74 \text { to } \\
0.12)\end{array}$ & $\begin{array}{l}0.697 \\
(0.40 \text { to } \\
0.99)\end{array}$ & 0.409 & 0.674 & 0.758 & 0.416 \\
\hline \multirow[t]{3}{*}{$\begin{array}{l}\text { to } \text { NOEC }_{\text {chronic }} \\
\text { from } \\
\text { EC50 }\end{array}$} & Fish & $\begin{array}{l}3.41 \\
(1.99 \text { to } 5.84)\end{array}$ & $\begin{array}{l}n=19 \\
n_{y}=38 \\
n_{x}=26\end{array}$ & $\begin{array}{l}-0.532 \\
(-0.77 \text { to } \\
-0.30)\end{array}$ & $\begin{array}{l}1.082 \\
(0.93 \text { to } \\
1.23)\end{array}$ & 0.415 & 0.437 & 0.933 & 0.926 \\
\hline & Invertebrates & $\begin{array}{l}2.68 \\
(2.19 \text { to } 3.28)\end{array}$ & $\begin{array}{l}n=89 \\
n_{y}=168 \\
n_{x}=173\end{array}$ & $\begin{array}{l}-0.427 \\
(-0.52 \text { to } \\
-0.34)\end{array}$ & $\begin{array}{l}0.92 \\
(0.84 \text { to } \\
0.99)\end{array}$ & 0.406 & 0.418 & 0.870 & 0.862 \\
\hline & $\begin{array}{l}\text { Algae and } \\
\text { bacteria }\end{array}$ & $\begin{array}{l}3.91 \\
\text { (3.29 to } 4.65)\end{array}$ & $\begin{array}{l}n=399 \\
n_{y}=763 \\
n_{x}=881\end{array}$ & $\begin{array}{l}-0.593 \\
(-0.67 \text { to } \\
-0.52) \\
\end{array}$ & $\begin{array}{l}0.93 \\
(0.89 \text { to } \\
0.98)\end{array}$ & 0.514 & 0.525 & 0.800 & 0.792 \\
\hline \multirow[t]{2}{*}{$\begin{array}{l}\text { to } \text { NOEC }_{\text {chronic }} \\
\text { from } \\
\text { NOEC }_{\text {acute }}\end{array}$} & Fish & $\begin{array}{l}3.14 \\
(1.48 \text { to } 6.63)\end{array}$ & $\begin{array}{l}n=31 \\
n_{y}=82 \\
n_{x}=45\end{array}$ & $\begin{array}{l}-0.496 \\
(-0.82 \text { to } \\
-0.17)\end{array}$ & $\begin{array}{l}0.969 \\
(0.77 \text { to } \\
1.17)\end{array}$ & 0.779 & 0.781 & 0.781 & 0.779 \\
\hline & Invertebrates & $\begin{array}{l}3.11 \\
(2.12 \text { to } 4.56)\end{array}$ & $\begin{array}{l}n=137 \\
n_{y}=225 \\
n_{x}=217\end{array}$ & $\begin{array}{l}-0.492 \\
(-0.66 \text { to } \\
-0.33) \\
\end{array}$ & $\begin{array}{l}0.620 \\
(0.51 \text { to } \\
0.73)\end{array}$ & 0.857 & 1.037 & 0.482 & 0.242 \\
\hline \multirow[t]{2}{*}{$\begin{array}{l}\text { to } \mathrm{NOEC}_{\text {chronic }} \\
\text { from } \\
\text { EC10 } \\
\text { chronic }\end{array}$} & Invertebrates & $\begin{array}{l}0.99 \\
(0.82 \text { to } 1.22)\end{array}$ & $\begin{array}{l}n=36 \\
n_{y}=70 \\
n_{x}=58\end{array}$ & $\begin{array}{l}0.0002 \\
(-0.09 \text { to } \\
0.09)\end{array}$ & $\begin{array}{l}0.977 \\
(0.88 \text { to } \\
1.07)\end{array}$ & 0.246 & 0.247 & 0.923 & 0.922 \\
\hline & $\begin{array}{l}\text { Algae and } \\
\text { bacteria }\end{array}$ & $\begin{array}{l}1.98 \\
(1.74 \text { to } 2.26)\end{array}$ & $\begin{array}{l}n=301 \\
n_{y}=558 \\
n_{x}=554\end{array}$ & $\begin{array}{l}-0.298 \\
(-0.35 \text { to } \\
-0.24) \\
\end{array}$ & $\begin{array}{l}0.978 \\
(0.94 \text { to } \\
1.02)\end{array}$ & 0.413 & 0.414 & 0.882 & 0.881 \\
\hline to $\mathrm{EC} 10_{\text {chronic }}^{\mathrm{eq}}$ & Fish & 1.55 & $n=9$ & -0.191 & $\begin{array}{l}1.031 \\
(0.83 \text { to }\end{array}$ & 0.347 & 0.428 & 0.952 & 0.951 \\
\hline
\end{tabular}

This article is protected by copyright. All rights reserved. 


\begin{tabular}{|c|c|c|c|c|c|c|c|c|c|}
\hline $\begin{array}{l}\text { Extrapolation } \\
\text { between } \\
\text { endpoints* }\end{array}$ & $\begin{array}{l}\text { Species } \\
\text { group }\end{array}$ & $\begin{array}{l}\text { Extrapolation } \\
\text { factor = } \\
1 / 10^{\text {intercept }} \\
(95 \% \text { CI })\end{array}$ & $\begin{array}{l}\text { Data } \\
\text { points } * *\end{array}$ & $\begin{array}{l}\text { Intercept } \\
\\
(95 \% \\
\text { CI })\end{array}$ & $\begin{array}{l}\text { Slope } \\
\text { (95\% CI) }\end{array}$ & $\begin{array}{l}\text { Standard } \\
\text { error }\end{array}$ & $\begin{array}{l}\begin{array}{l}\text { Standard } \\
\text { error, }\end{array} \\
\text { slope }=1\end{array}$ & $\mathbf{R}^{2}$ & $\begin{array}{l}\mathrm{R}^{2} \\
\text { slope } \\
=1\end{array}$ \\
\hline \multirow[t]{3}{*}{$\begin{array}{l}\text { from } \\
\text { EC50 } \\
\text { chronic }\end{array}$} & & $\begin{array}{l}(0.67 \text { to } \\
3.66)\end{array}$ & $\begin{array}{l}n_{y}=15 \\
n_{x}=14\end{array}$ & $\begin{array}{l}(-0.56 \text { to } \\
0.18)\end{array}$ & 1.24) & & & & \\
\hline & Invertebrates & $\begin{array}{l}1.94 \\
\text { (1.56 to } 2.41)\end{array}$ & $\begin{array}{l}n=76 \\
n_{y}=109 \\
n_{x}=149\end{array}$ & $\begin{array}{l}-0.288 \\
(-0.38 \text { to } \\
-0.19) \\
\end{array}$ & $\begin{array}{l}0.943 \\
(0.87 \text { to } \\
1.02)\end{array}$ & 0.348 & 0.354 & 0.843 & 0.802 \\
\hline & $\begin{array}{l}\text { Algae and } \\
\text { bacteria }\end{array}$ & $\begin{array}{l}2.24 \\
(1.90 \text { to } 2.65)\end{array}$ & $\begin{array}{l}n=312 \\
n_{y}=564 \\
n_{x}=656\end{array}$ & $\begin{array}{l}-0.351 \\
(-0.42 \text { to } \\
-0.28) \\
\end{array}$ & $\begin{array}{l}0.905 \\
(0.86 \text { to } \\
0.95)\end{array}$ & 0.452 & 0.478 & 0.836 & 0.809 \\
\hline \multirow[t]{2}{*}{$\begin{array}{l}\text { to } \mathrm{EC} 10_{\text {chronic }}^{\mathrm{eq}} \\
\text { from } \\
\text { NOEC }_{\text {chronic }}\end{array}$} & Invertebrates & $\begin{array}{l}0.95 \\
(0.77 \text { to } 1.16)\end{array}$ & $\begin{array}{l}n=36 \\
n_{y}=58 \\
n_{x}=70\end{array}$ & $\begin{array}{l}-0.022 \\
(-0.06 \text { to } \\
0.11)\end{array}$ & $\begin{array}{l}0.945 \\
(0.85 \text { to } \\
1.04)\end{array}$ & 0.242 & 0.247 & 0.923 & 0.919 \\
\hline & $\begin{array}{l}\text { Algae and } \\
\text { bacteria }\end{array}$ & $\begin{array}{l}0.44 \\
(0.39 \text { to } 0.49)\end{array}$ & $\begin{array}{l}n=301 \\
n_{y}=554 \\
n_{x}=558\end{array}$ & $\begin{array}{l}0.359 \\
(0.31 \text { to } \\
0.41)\end{array}$ & $\begin{array}{l}0.902 \\
(0.86 \text { to } \\
0.94)\end{array}$ & 0.397 & 0.520 & 0.882 & 0.870 \\
\hline \multirow[t]{2}{*}{$\begin{array}{l}\text { to EC10 } \\
\text { from } \mathrm{EC} 50_{\text {acute }}\end{array}$} & Fish & $\begin{array}{l}7.44 \\
(2.92 \text { to } \\
18.95)\end{array}$ & $\begin{array}{l}n=26 \\
n_{y}=29 \\
n_{x}=44\end{array}$ & $\begin{array}{l}-0.871 \\
(-1.28 \text { to } \\
-0.46)\end{array}$ & $\begin{array}{l}1.036 \\
(0.74 \text { to } \\
1.33)\end{array}$ & 0.817 & 1.175 & 0.685 & 0.682 \\
\hline & Invertebrates & $\begin{array}{l}3.38 \\
(2.14 \text { to } 5.34)\end{array}$ & $\begin{array}{l}n=93 \\
n_{y}=129 \\
n_{x}=198\end{array}$ & $\begin{array}{l}-0.529 \\
(-0.73 \text { to } \\
-0.33) \\
\end{array}$ & $\begin{array}{l}0.680 \\
(0.55 \text { to } \\
0.81)\end{array}$ & 0.718 & 0.881 & 0.559 & 0.339 \\
\hline \multirow[t]{2}{*}{$\begin{array}{l}\text { to } \mathrm{EC} 10_{\text {chronic }}^{\mathrm{eq}} \\
\text { from } \\
\text { NOEC }_{\text {acute }}\end{array}$} & Fish & $\begin{array}{l}3.97 \\
(0.90 \text { to } \\
17.39)\end{array}$ & $\begin{array}{l}n=12 \\
n_{y}=12 \\
n_{x}=14\end{array}$ & $\begin{array}{l}-0.598 \\
(-1.24 \text { to } \\
0.04)\end{array}$ & $\begin{array}{l}0.897 \\
(0.35 \text { to } \\
1.45)\end{array}$ & 0.989 & 1.203 & 0.568 & 0.541 \\
\hline & Invertebrates & $\begin{array}{l}1.55 \\
(0.91 \text { to } 2.64)\end{array}$ & $\begin{array}{l}n=77 \\
n_{y}=110\end{array}$ & $\begin{array}{l}-0.190 \\
(-0.42 \text { to }\end{array}$ & $\begin{array}{l}0.456 \\
(0.29 \text { to } \\
0.62)\end{array}$ & 0.861 & 1.162 & 0.294 & 0.222 \\
\hline
\end{tabular}

This article is protected by copyright. All rights reserved. 


\begin{tabular}{|c|c|c|c|c|c|c|c|c|c|}
\hline $\begin{array}{l}\text { Extrapolation } \\
\text { between } \\
\text { endpoints* }\end{array}$ & $\begin{array}{l}\text { Species } \\
\text { group }\end{array}$ & 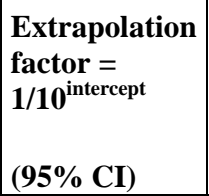 & $\begin{array}{l}\text { Data } \\
\text { points** }\end{array}$ & $\begin{array}{l}\text { Intercept } \\
\\
(95 \% \\
\text { CI })\end{array}$ & \begin{tabular}{|l|} 
Slope \\
$(95 \% \mathrm{CI})$
\end{tabular} & $\begin{array}{l}\text { Standard } \\
\text { error }\end{array}$ & $\begin{array}{l}\begin{array}{l}\text { Standard } \\
\text { error, }\end{array} \\
\text { slope }=1\end{array}$ & $\mathbf{R}^{2}$ & $\begin{array}{l}\mathbf{R}^{2}, \\
\text { slope } \\
=1\end{array}$ \\
\hline & & & $n_{x}=127$ & 0.04) & & & & & \\
\hline
\end{tabular}

* NOEC = No-Observed Effect Concentration; EC50 = Effect concentration inducing a $50 \%$ response over background; EC10 ${ }^{\mathrm{eq}}=$ combined set of LOEC (Lowest Observed Effect Concentration) and EC10 (Effect concentration inducing a 10\% response over background)

** $n$ represents the number of averaged data points, while $n_{x}$ and $n_{y}$ indicate the numbers of total individual data points per reported endpoints $x$ and $y$.

Table 4. Recommended default extrapolation factors (slope set to unity), 95\% confidence interval (CI) ranges and best-fit extrapolation factors for chronic ecotoxicity effect endpoints EC50, NOEC, and EC10

\begin{tabular}{|c|c|c|}
\hline $\begin{array}{l}\text { Recommended default } \\
\text { extrapolation* }\end{array}$ & $\begin{array}{l}\text { Default } \\
\text { extrapolation } \\
\text { factors (95\% } \\
\text { CI) }\end{array}$ & Best-fit extrapolation \\
\hline $\mathrm{EC} 50_{\text {chronic }}=\frac{\mathrm{EC} 50_{\text {acute }}}{2}$ & $2(1.8-3.4)$ & $E C 50_{\text {chronic }}=\frac{\left(\mathrm{EC} 50_{\text {acute }}\right)^{0.9}}{2.5}$ \\
\hline $\mathrm{EC} 50_{\text {chronic }}=\frac{\mathrm{NOEC}_{\text {chronic }}}{0.4}$ & $0.4(0.2-0.6)$ & $\mathrm{EC} 50_{\text {chronic }}=\frac{\left(\mathrm{NOEC}_{\text {chronic }}\right)^{0.9}}{0.3}$ \\
\hline $\mathrm{EC} 50_{\text {chronic }}=\frac{\mathrm{NOEC}_{\text {acute }}}{1.2}$ & $1.2(0.7-1.9)$ & $\mathrm{EC} 50_{\text {chronic }}=\frac{\left(\mathrm{NOEC}_{\text {acute }}\right)^{0.7}}{1.1}$ \\
\hline $\mathrm{EC} 50_{\text {chronic }}=\frac{\mathrm{EC} 10_{\text {chronic }}^{\mathrm{eq}}}{0.5}$ & $0.5(0.2-0.8)$ & $\mathrm{EC} 0_{\text {chronic }}=\frac{\left(\mathrm{EC} 10_{\text {chronic }}^{\mathrm{eq}}\right)^{0.9}}{0.35}$ \\
\hline $\mathrm{NOEC}_{\text {chronic }}=\frac{\mathrm{EC} 50_{\text {acute }}}{5}$ & $5(3.8-7.5)$ & $\mathrm{NOEC}_{\text {chronic }}=\frac{\left(\mathrm{EC} 50_{\text {acute }}\right)^{0.8}}{5.4}$ \\
\hline
\end{tabular}

This article is protected by copyright. All rights reserved. 


\begin{tabular}{|c|c|c|}
\hline $\begin{array}{l}\text { Recommended default } \\
\text { extrapolation* }\end{array}$ & $\begin{array}{l}\text { Default } \\
\text { extrapolation } \\
\text { factors (95\% } \\
\text { CI) }\end{array}$ & Best-fit extrapolation \\
\hline $\mathrm{NOEC}_{\text {chronic }}=\frac{\mathrm{EC} 50_{\text {chronic }}}{3.3}$ & $3.3(3.0-4.1)$ & $\mathrm{NOEC}_{\text {chronic }}=\frac{\left(\mathrm{EC} 50_{\text {chronic }}\right)^{0.9}}{3.5}$ \\
\hline $\mathrm{NOEC}_{\text {chronic }}=\frac{\mathrm{NOEC}_{\text {acute }}}{3.1}$ & $3.1(2.2-4.4)$ & $\mathrm{NOEC}_{\text {chronic }}=\frac{\left(\mathrm{NOEC}_{\text {acute }}\right)^{0.7}}{3.13}$ \\
\hline $\mathrm{NOEC}_{\text {chronic }}=\frac{\mathrm{EC} 10_{\text {chronic }}^{\mathrm{eq}}}{1.7}$ & $1.7(1.5-2.1)$ & $\mathrm{NOEC}_{\text {chronic }}=\frac{\left(\mathrm{EC} 10_{\text {chronic }}^{\mathrm{eq}}\right)^{0.7}}{1.8}$ \\
\hline $\mathrm{EC}_{10}^{\mathrm{eq}}{ }_{\text {chronic }}=\frac{\text { NOEC }_{\text {acute }}}{1.8}$ & $1.8(1.0-2.7)$ & $\mathrm{EC} 0_{\text {chronic }}^{\mathrm{eq}}=\frac{\left(\mathrm{NOEC}_{\text {acute }}\right)^{0.7}}{1.9}$ \\
\hline $\mathrm{EC} 10_{\text {chronic }}^{\mathrm{eq}}=\frac{\mathrm{EC} 50_{\text {acute }}}{4}$ & $4(2.6-6.1)$ & $\mathrm{EC} 10_{\text {chronic }}^{\mathrm{eq}}=\frac{\left(\mathrm{EC} 50_{\text {acute }}\right)^{0.9}}{4.7}$ \\
\hline $\mathrm{EC} 10_{\text {chronic }}^{\mathrm{eq}}=\frac{\mathrm{NOEC}_{\text {chronic }}}{0.6}$ & $0.6(0.4-0.7)$ & $\mathrm{EC} 10_{\text {chronic }}^{\mathrm{eq}}=\frac{\left(\mathrm{NOEC}_{\text {chronic }}\right)^{0.9}}{0.53}$ \\
\hline $\mathrm{EC} 10_{\text {chronic }}^{\mathrm{eq}}=\frac{\mathrm{EC} 0_{\text {chronic }}}{2}$ & $2(1.8-2.5)$ & $\mathrm{EC} 10_{\text {chronic }}^{\mathrm{eq}}=\frac{\left(\mathrm{EC} 50_{\text {chronic }}\right)^{0.9}}{2.16}$ \\
\hline
\end{tabular}

*NOEC $=$ No-Observed Effect Concentration; EC50 = Effect concentration inducing a $50 \%$ response over background; EC10 ${ }^{\mathrm{eq}}=$ combined set of LOEC (Lowest Observed Effect Concentration) and EC10 (Effect concentration inducing a 10\% response over background)

This article is protected by copyright. All rights reserved. 